\title{
IMPORTANCE OF PATCh SCALE VS. LANDSCAPE SCALE ON SELECTED FOREST BIRDS.
}

\author{
By \\ Michelle Lee \\ A thesis submitted to \\ the Faculty of Graduate Studies and Research \\ in partial fulfillment of \\ the requirements for the degree of \\ Masters of Science \\ Department of Biology \\ Carleton University \\ Ottawa. Ontario \\ July 1999 \\ (C) 1999. Michelle Lee
}


National Library

of Cariada

Acquisitions and Bibliographic Services

395 Wellington Street Ottawa ON KIA ON4 Canada
Bibliothèque nationale

du Canada

Acquisitions et services bibliographiques

395, rue Wellington

Ontawa ON K1A ON4

Canada
The author has granted a nonexclusive licence allowing the National Library of Canada to reproduce, loan, distribute or sell copies of this thesis in microform, paper or electronic formats.
L'auteur a accordé une licence non exclusive permettant à la Bibliothèque nationale du Canada de reproduire, prêter, distribuer ou vendre des copies de cette thèse sous la forme de microfiche/film, de reproduction sur papier ou sur format électronique.

L'auteur conserve la propriété du droit d'auteur qui protège cette thèse. $\mathrm{Ni}$ la thèse ni des extraits substantiels de celle-ci ne doivent être imprimés ou autrement reproduits sans son autorisation. 


\section{ABSTRACT}

The management and protection of natural areas has primarily occurred in isolation from surrounding land management. The structure of surrounding land cover however, may be very important to the abundance and reproductive success of certain species within a habitat patch. The purpose of this study was to investigate the relative importance of forest patch area, core area (forest $>100 \mathrm{~m}$ from an edge), and surrounding landscape forest cover on Wood Thrush. Red-eyed Vireo and Ovenbird densities, and on Ovenbird pairing success. I selected 31 isolated forest patches and 380 -ha plots in continuous forest. centred within non-overlapping $2 \mathrm{~km}^{2}$ landscapes, such that patch area and landscape forest cover were uncorrelated among landscapes. Each study plot was surveyed comprehensively to determine density of the target species and Ovenbird pairing success. Ovenbird density was best predicted by the amount of landscape forest cover $(p=0.02)$. Wood Thrush density was positively correlated with patch core area ( $p$ $=0.04)$ and patch size $(p=0.04)$. Red-eyed Vireo density decreased with forest patch area $(p=0.0005)$. Ovenbird pairing success was significantly higher in continuous torest plots than in forest patches $(p=0.018)$. The conservation implications are: $(1)$ bird species which may appear to have similar habitat needs respond very differently to the structure of habitat within a landscape, and (2) for some bird species. the amount of torest cover in the surrounding landscape may be important for their conservation. 


\section{ACKNOWLEDGEMENTS}

Thanks to my supervisor. Lenore Fahrig. co-supervisor Kathy Freemark. and committee member David Currie. who provided me with guidance and feedback throughout many stages of my research. I am indebted to my field assistants. Patti Swan. Juliette Faure. and Sarah Peters who endured the heat, rain and mosquitoes to make this project possible. Carleton ecology lab members and those closely affiliated with the lab positively affected my research and writing by providing a stimulating work environment, and by offering helpful feedback and advice. Thanks to Brian Leung for our many entertaining statistical conversations. I am particularly grateful to Darren Bender and Tom Contreras who frequentiy put aside their own work to patiently answer my many GIS and statistical questions. Finally, this work could not have been completed without moral support from the Lees (Ted. Norma and Chris) and from the Elliott clan. Mike Elliott. in particular was an endless source of encouragement and a participant in all stages of the project. Funding for this research was provided by Carleton University. an Ontario Government Scholarship and NSERC research grants to Lenore Fahrig. Kathy Freemark and myself. 


\section{TABLE OF CONTENTS}

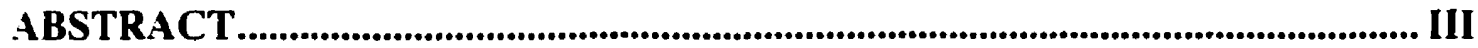

ACKNOWLEDGEMENTS …...................................................................................IV

TABLE OF CONTENTS ….............................................................................................. V

LIST OF TABLES ..........................................................................................................

LIST OF FIGURES ............................................................................................................ VIII

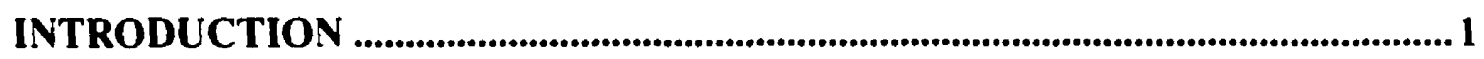

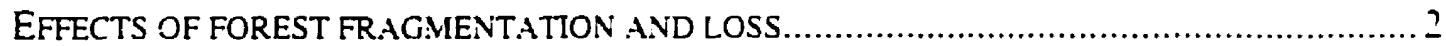

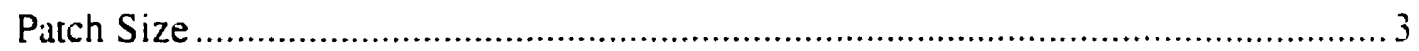

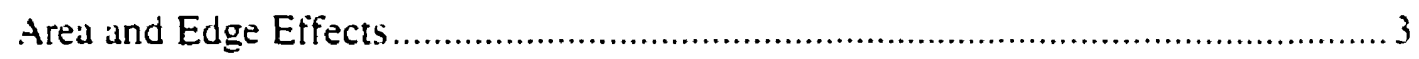

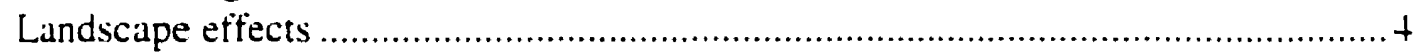

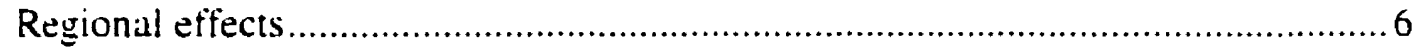

The Relationship between Forest Fragmentation and Loss................................. 6

Problems with current landscape effect studies ................................................ 7

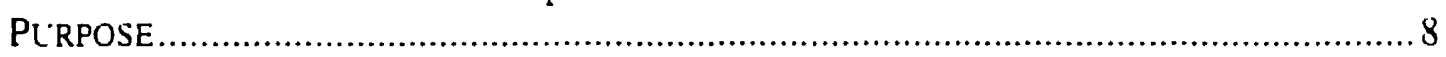

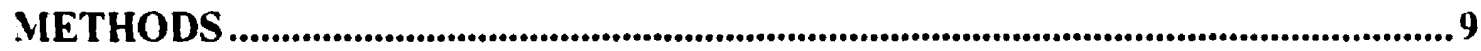

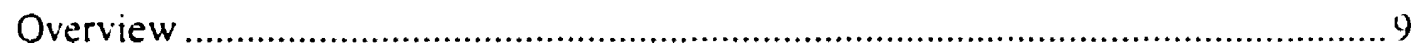

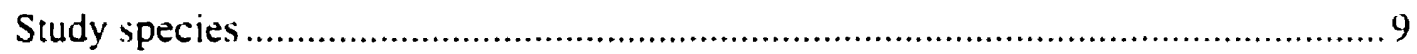

QLAITIFYLNG WITHIN-PATCH CHARACTERISTICS .......................................... 11

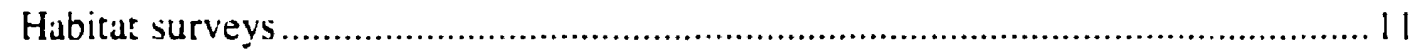

QLANTIFYING PATCH AND LANDSCAPE CHARACTERISTICS .................................. 13

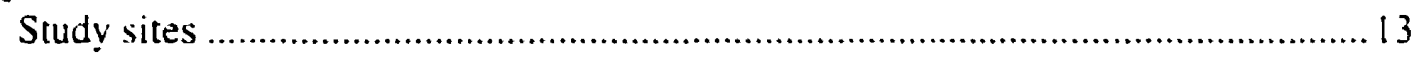

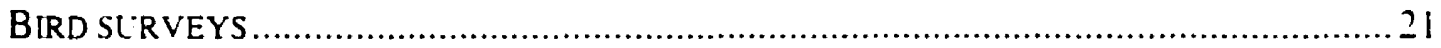

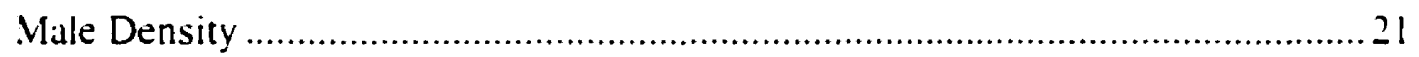

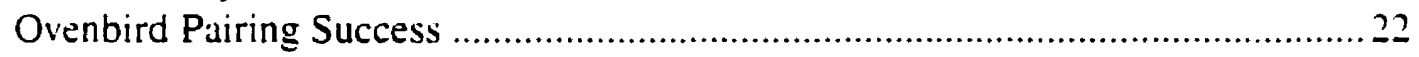

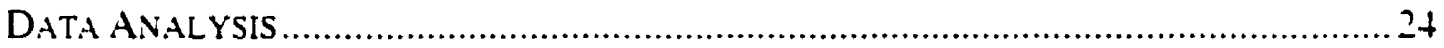

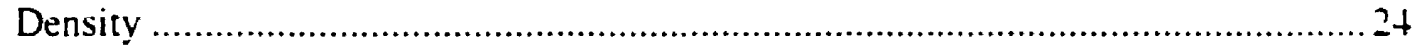

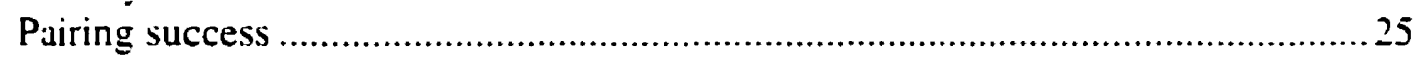

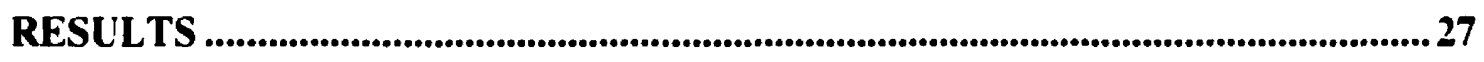

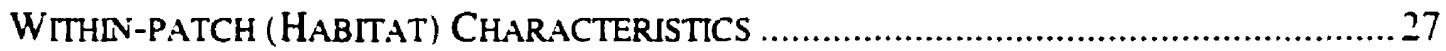

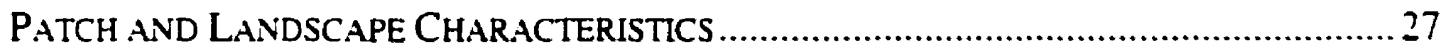

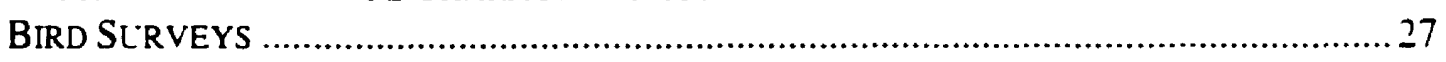

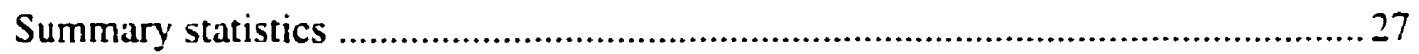

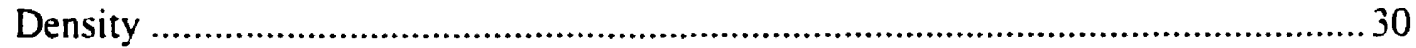

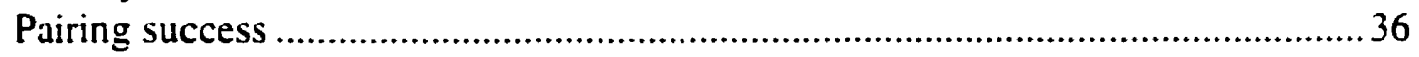




\section{Table of Contents, Continued}

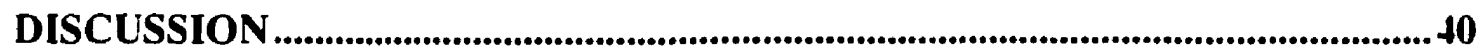

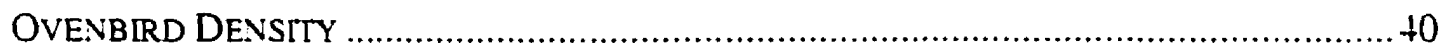

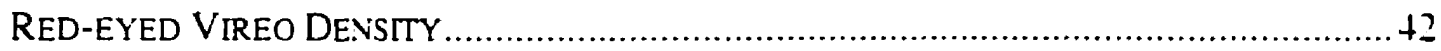

WOOD THRLSH DENSTTY ............................................................................ 43

LNTERSPECIFIC DIFFERENCES ...................................................................... +3

OVE.NBIRD PAIRING SLCCESS ....................................................................

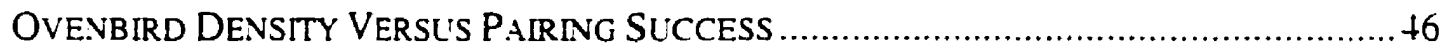

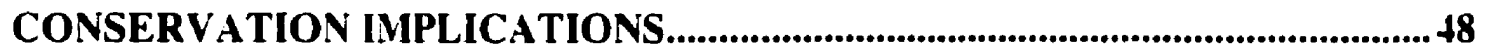

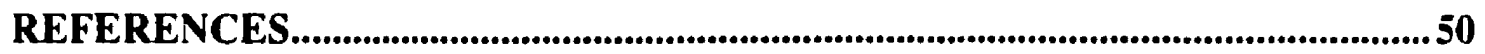




\section{LIST OF TABLES}

Table 1 . Habitat measurements taken at Ovenbird singing perches in each of the $3+$ focal forest patches

Table 2. Landscape characteristics for each $2 \mathrm{~km}^{2}$ study landscape. Total forest cover is the sum of focal forest patch size and surrounding forest cover. Core area is calculated based on an edge width of $100 \mathrm{~m}$.

Table 3. Pearson s correlation coefficients for landscape and patch variables. 28

Table 4 . Summary statistics of bird abundance and density based on maximum number of male detections per patch for Ovenbird. Wood Thrush and Red-eyed Vireo. Standard deviations are indicated in brackets.

Table 5. T-test comparison of Ovenbird pairing success in continuous forests and torest patches 


\section{LiST OF Figures}

Figure 1. Study region near Ottawa. Ontario. Thirty-four $-2 \mathrm{~km}^{2}$, non-overlapping landscapes were selected for study. Each study landscape was centred on a focal forest patch in which bird and habitat surveys were conducted. See Table 2 for site details.

Figure 2. Representation of landscape and patch selection. Study landscapes were selected to represent a range in percent forest cover surrounding the focal patch such that the 2 variables were uncorrelated.

Figure 3. Relationship between male Ovenbird density in a tocal forest patch/plots and proportion of forest cover in the surrounding $2 \mathrm{~km}^{2}$ landscape $(\mathrm{n}=34)$.

Figure 4. Relationship between male Red-eyed Vireo density and focal forest patch/plot area $(n=34)$.

Figure 5a. Relationship between rank Wood Thrush density and patch/plot area $(n=34)$.

Figure 5b. Relationship between Wood Thrush density and core area $(n=34)$. 34

Figure 5c. Relationship between Wood Thrush density and tree density (n $=34$ ). .35

Figure 6. Relationship between male Ovenbird pairing success and focal forest patch area $(n=25)$. Regression results for this relationship were not significant $(p>0.05)$.

Figure 7. Difference in pairing success between 22 forest patches and 3 continuous forests. Bars represent one standard error from the mean. 


\section{INTRODUCTION}

The recent unprecedented rate of forest destruction and fragmentation is considered one of the greatest contributing factors to the decline of many Neotropical migrant bird species in their breeding range (see Askins et al. 1990 for review). In southern Canada. intensification of agricultural and urban development has reduced many large continuous and connected forest tracts to small. isolated forest fragments. Coinciding with changes in habitat. 45 percent of Canadian long-distance migrants have declined in abundance between 1966 and 1994 (CWS 1998).

A parsimonious explanation for Neotropical migrant bird trends attributes their decline solely to habitat loss. This explanation is based on the species-area relationship (Connor and McCoy 1979), and the random sample hypothesis (Haila 1983. Andren 1994). When applied to terrestrial habitat "islands", the hypotheses propose that the number of species in a habitat fragment declines with the reduction in size of that friagment (species-area relationship), and that those species remaining in small fragments will be a random sample from larger ones (random sample hypothesis).

Scientific interest in the effects of forest fragmentation on avian populations grew when it became evident that the decline in species abundance and richness was greater than that which would be expected by forest loss alone. A growing amount of evidence suggests that bird assemblages recorded in small forest fragments are nested subsets of those found in larger forests. rather than a random sample (see Hayden et al. 1985. Blake and Karr 1987. Bolger et al. 1991. Blake 1991).

In addition. a number of studies indicate that certain species are conspicuously absent from small patches more often than would be expected by chance - even when 
regional abundance (i.e. rarity) is taken into account (e.g. Bond 1957. Galli et al. 1976. Forman et al. 1976. Robbins 1979. Whitcomb et al. 1981. Lynch and Whigham 1984. Blake and Karr 1987). The species-area and random sample hypotheses do not fully explain bird population declines primarily because they fail to account for important effects beyond patch size, such as edge effects. patch isolation and effects of surrounding forest cover in the landscape.

In light of the insufficiency of hypotheses based on patch size to explain the magnitude of avian population declines, most recent research has focused on the theory of island biogeography (MacArthur and Wilson 1967). For forest patches surrounded by a non-forest matrix such as agricultural land, the island biogeography theory proposes that the number of resident species decreases with both a reduction in patch size and with increasing isolation of that patch from other habitat. Despite its shortcomings (Boecklen and Gotelli 1984. Merriam 1988. Hanski and Simberloff 1997), island biogeography and its key principles (species-area relationships and isolation) pervade current research on avian populations in fragmented landscapes (Wiens 1994).

\section{EfFects of Forest Destrcction and Fragmentation}

Landscapes that have experienced forest destruction and fragmentation are generally characterized by smaller mean forest patch size, patches with greater edge to interior habitat ratios. increased patch isolation. 


\section{Patch Size}

As predicted by the species-area curve. species richness and population abundance both decline as forest is reduced in size. Remaining small populations are mote vulnerable to local extinctions and a reduction in genetic diversity if immigration is limited (Levins 1970, Verboom et al. 1991). If a torest patch becomes smaller than the home range or territory size of an individual. the spectes usually disappear from the patch altogether.

\section{Area and Edge Effects}

Area and edge effects occur in addition to declines in avian species richness and population abundance due to reduced patch size. Interior forest specialists in small patches are necessarily closer to the forest edge than those in large. continuous forests and thus are exposed to different physical and biological conditions to which they are poorly adapted. Changes in microclimate. vegetation (see review by Saunders et al. 1991. Burke and Nol 1998a) and food availability (Burke and Nol i998b) at forest edges may be responsible for lower bird densities found there compared with interior forest habitat. Vegetation species richness can also increase with patch size (Williams 1964). which in turn may increase bird species diversity and abundance.

Patch size and proximity to edge can also affect reproductive success. Lower rates of pairing success for males at forest edges compared with forest interiors ( $V$ an Horn 1990) may be linked to decreased food availability and a lack of adequate nesting sites (Burke and Nol 1998b). Rates of nest parasitism by Brown-headed Cowbirds (Molothrus ater) and nest predation are higher in small, edge dominated forests, than in 
larger forests with ample forest interior habitat (see review by Paton 1994). Smaller patches may also not be able to support top predators that normally control predators of ground nesting birds, such as small mammals (Wilcove et al. 1986). Herbivores proliferate without population control by top predators. and bird habitat may be altered through increased browsing (Angelstam 1992. DeCalesta 1994). Finally. torest bird competition with habitat generalists has been shown in some studies to increase as patch size decreases (Wilcove and Robinson 1990).

\section{Landscape effects}

Although torest patch size has been best documented as a major predictor of species richness, density and reproductive success (Freemark et al. 1995). many ecologists now propose that landscape scale factors moderate forest area effects (Saunders et al. 1991. Freemark and Collins 1992. Roth and Johnson 1993. Fahrig and Merriam 1994. Robinson et al 1995). Variations in patch level effects that are not accounted for by patch size may be due to the structure and configuration of local landscape in which the patch is imbedded (Donovan et al. 1997). In a review of 49 papers on birds and mammals. Andren (1994) found that area and isolation effects were detected in highly fragmented landscapes when total habitat cover ranged from 10 to 30 percent. but were not detected in landscapes with over 30 percent habitat cover. In addition. Donovan et al. (1997) found that the percent of forest cover in the landscape affected the existence of edge effects.

Hypotheses to explain processes occurring beyond the individual patch level often stress the importance of forest patch isolation. The theory of island biogeography 
proposes that the proximity of a forest patch to surrounding habitat is important because it limits the successful dispersal of individuals (MacArthur and Wiison 1967). Isolated forest patches may have limited immigration due to high mortality rates in dispersers while traversing non-habitat that separates patches, or behaviour in species that prevents them from crossing non-habitat. If avian populations function as metapopulations (subdivided local populations that interact through immigration and emigration). low dispersal between patches may result in more local extinctions and low genetic variability (Levins 1970).

Movement of individuals between forest patches does not depend entirely on the distance that separates habitat patches: landscape configuration and composition also greatly affect dispersal. Landscape connectivity (sensu Merriam 1984), expressed as al less hostile inter-patch landscape (i.e. matrix). in conjunction with the presence of fencerows, riparian strips or small "stepping stone" patches. can facilitate forest bird movement and provide the safety of cover during dispersal (e.g. Haas 1995).

Landscape structure influences more than dispersal among patches. Local predator and parasite abundance. which can both modify mortality and recruitment rates of forest birds. are affected by landscape structure. Landscapes with certain proportions of both agricultural land and forest cover support the breeding and foraging needs of Cowbirds (Thompson 1994), which can increase nest parasitism rates (Saab 1999: but see Tewksbury et al. 1998). Densities of some predators such as raccoons and crows (Andren 1992) and nest predation rates (Donovan et al. 1997) are greater in highly fragmented landscapes. Recruitment can be sufficiently low in highly fragmented 
landscapes. due to nest parasitism and predation (Robinson et al. 1995), that they support only population sinks (Brawn and Robinson 1996. Bollinger et al. 1997).

\section{Regional effects}

The effects of forest loss and fragmentation vary in severity according to the geographical location of the study (e.g. Villard et al. 1993. Hahn and Hatfield 1994. Tewksbury et al. 1998). Differences in landscape structure at a regional scale may account for some of the inconsistent results between local level studies. Predator communities may also vary across regions. giving rise to differential predation rates in different studies (Tewskbury et al. 1998). Populations that exist on the periphery of their range and already live in marginal habitat may be more susceptible to habitat loss effects (Brown 1984).

\section{The Relationship between Forest Fragmentation and Loss}

Analyses of forest loss and fragmentation patterns in simulated landscapes has revealed that characteristics such as patch size, patch isolation and proportion of forest in the landscape. are highly interrelated. Simulations of landscape patterns by Gustafison and Parker (1992) and Andren (1994) have shown that these relationships are rarely linear: as the proportion of forested land increases, mean patch area in a landscape increases exponentially and isolation of those patches decreases exponentially. In addition. as total habitat cover in a landscape is reduced, fragmentation tends to increase until a threshold point. 
The relationship between fragmentation and habitat loss makes analysis of their independent effects difficult (Haila and Hanski 1984). Proponents for the consideration of forest fragmentation separately from forest loss point out that understanding the independent effects of each is necessary for effective land management (Fahrig and Grez 1996. Fahrig 1997). However. most researchers continue to treat habitat loss and habitat fragmentation as one process because the two rarely occur independently in the natural world. Consequently, the effects of fragmentation per se. without confounding forest loss effects. are not well understood (but see Fahrig 1997. Trzcinski et al. 1999).

\section{Problems with current landscape effect studies}

Due to the positive relationship between patch size and the proportion of forest cover in the landscape, the separation of their effects is difficult (Pearson 1993). Most studies confound the effects of isolation or local forest cover and patch size or suffer from spatial autocorrelation caused by overlapping landscapes or clustered forest study patches (e.g. Whitcomb et al. 1981. Villard et al. 1993). Studies often report an inadequate range in the levels of isolation among patches, or do not report the variation in isolation at all (e.g. Gibbs and Faaborg 1990. Villard et al. 1993). Moreover. the matrix is rarely considered. even though variable matrix types (e.g. urban. agriculture) between different isolated forest patches may alter population responses to fragmentation (e.g. Whitcomb et al. 1981).

The focus of research on patch-scale processes. such as area and edge effects. has led to the assumption that patch effects are more significant than other effects. This focus may be unwarranted due to the paucity of studies that compare the relative 
importance of patch and landscape effects (but see review by Mazerolle and Villard 1999). Since the relative importance of landscape and patch effects is a key consideration when determining priorities for habitat preservation or reserve creation. landscape studies must be designed to separate these effects.

\section{PurPose}

In this paper I evaluate the independent effects of within-patch characteristics (habitat). patch characteristics (forest patch size and core area) and landscape characteristics (proportion of forest cover in the landscape) on bird density and pairing success for selected species of Neotropical migrant birds. 


\section{MeThods}

\section{Overview}

Ovenbird (Seiurus aurocapillus). Wood Thrush (Hylocichla mustelina) and Redeyed Vireo (Vireo olitaceus) density and Ovenbird pairing success were estimated in 31 focal forest patches and 3 forest plots within continuous forest. Each surveyed focal forest patch and plot was located in the centre of a square. $2 \mathrm{~km}^{2}$ landscape that was comprised of a mix of forest cover and agricultural land. Focal forest patches and plots with a relatively low edge to interior ratio were chosen over long sinuous patches with higher edge to interior ratios to avoid confounding effects arising from differently shaped patches. Patches and plots were chosen to represent a range in size. while landscapes were chosen to represent a range in torest cover. such that the two varied independently of each other.

\section{Study species}

The target species were selected because of their apparent sensitivity to both patch scale and landscape scale processes. Patch scale studies of the target species indicate that they increase in population density or frequency with increased forest patch size (see review by Freemark et al. 1995). Although there is some evidence that the 3 species avoid habitat edges (summarized by Villard 1998), other research suggests that Red-eyed Vireos and Wood Thrush are forest interior and edge specialists (Freemark and Collins 1992). Additionally, reproductive success as estimated by pairing success (Wander 1985. Gentry 1989. Wenny 1989. Gibbs and Faaborg 1990. Porneluzi et al. 1993). nest parasitism (Brittingham and Temple 1983. Robinson et al.1995. Donovan et 
al. 1995. Burke 1998) and nest predation (Wilcove 1985. Hoover et al. 1995. Donovan et al. 1995. Burke 1998), is apparently lower in small patches than in larger patches or continuous forests for these species.

Habitat isolation. as measured by landscape forest cover and inter-patch distance has also been linked to the abundance and reproductive success of the target species. In general, it has been found that as forest isotation increases. i.e. as landscape forest cover decreases, the abundance and reproductive success of the target species declines (Whitcomb et al. 1981. Lynch and Whigham 1984, Askins and Philbrick 1987. Robbins et al. 1989. Robinson 1992. Roth et al. 1996. Donovan et al. 1997). However. this relationship has not been consistent across all studies (for example. see Donovan et al. 1995. Bender et al. 1998. and Burke 1998)

Males of all 3 study species are territorial and establish mating territories as soon as they return to their breeding habitat in late April and early May. Male Ovenbirds establish territories in Ontario that range from 0.61 to 1.60 hectares (ha) in size iStenger 1958). and lay their fïrst and second broods between May 26 and July 15 (James et al. 1976). Territory intruders are actively deterred by male Ovenbirds through song from the onset of territory establishment. Singing by Ovenbird males is more frequent and aggressive during territory establishment and less frequent once a mate has been secured (Hann 1937. Lein 1980. Gibbs 1988. Van Horn 1990). Red Eyed Vireo and Wood Thrush males usually establish territories of less than 2 ha (Freemark and Merriam 1986). Both species lay eggs between May 18 and Aug 10 (James et al. 1976). 


\section{QLANTIFYING WithIN-PATCH CHARACTERISTICS}

\section{Habitat surveys}

Local habitat characteristics were considered to avoid spurious results that would arise if patch or landscape characteristics were correlated with within-patch variables. Habitat characteristics (Table I) were collected from each focal forest patch using a point-quarter method. Ice storm damage measurements were included to account for possible habitat differences between forest patches caused by a severe ice storm that occurred in 1997. the winter prior to sampling.

A systematic sampling design was used to accommodate the design of a concurrent study that compared microhabitat differences in Ovenbird territories and nonterritories (Swan 1999). While a random sampling design may have better characterized within-patch characteristics of focal forest patches. the systematic sampling scheme still provided an estimate of within-patch characteristics across a relatively even distribution of sampling points in space.

Vegetation measurements were taken at both Ovenbird territory and non-territory locations. A minimum of 2 point quarter measurements was taken in very small focal patches and a maximum of 6 point quarter measurements was taken in larger focal patches. Flagged singing perches were used for measurements of vegetation within territories only if a male Ovenbird had been recorded within a 10 metre radius of the singing perch on at least 2 of 3 separate visits. Where possible, habitat at the base of the singing perch for at least I paired and I unpaired male Ovenbird was measured per focal forest patch. The non-territory locations were first randomly selected outside of known 
Table I. Habitat measurements taken at Ovenbird singing perches in each of the 34 focal forest patches.

\begin{tabular}{ll}
\hline \multicolumn{1}{c}{ Habitat characteristics } & \multicolumn{1}{c}{ Ice storm damage estimates } \\
\hline \hline diameter at breast height (DBH) & percent crown loss ${ }^{2}$ \\
percent living ground cover & tree damage index ${ }^{\mathrm{b}}$ \\
leaf litter depth & coarse woody debris index \\
herb height & \\
shrub height & \\
canopy cover & \\
tree density \\
tree height \\
tree species richness \\
percent deciduous species
\end{tabular}

\lrcorner (Fahrig and Contreras pers.comm.)

${ }^{\text {h }}$ Six damage clatsises used to estimated ot size of tree limbs lost in past year (Fahrig and Contreras pers.comm. modified after Rebertus et al. 1997)

- IFahrig and Contreras pers.comm.. modified after Bruederle and Stearns 1985. Reberrus at al. 19971. 
territory locations. and then confirmed with song playbacks to ensure that Ovenbirds did not respond.

\section{QcaNtifying Patch and LandSCAPE ChaRacteristics}

Study sites

The study area. located within $100 \mathrm{~km}$ of Ottawa. Ontario. is characterized by a scattered pattern of small forest patches embedded in a primarily agricultural landscape. Most remaining forest patches are located on poorly drained soils of low agricultural value. Forest patches in the region are relatively mature and dominated by Sugar Maple (Acer saccharum). White Ash (Fraxinus americana). American Basswood (Tilia americana), and Ironwood (Ostria virginiana), with a small occurrence of Eastern White Pine (Pinus strobus) and Eastern Hemlock (Tsuga cunadensis).

Thirty-four - $2 \mathrm{~km}^{2}$ (200 ha) landscapes were selected for study (Figure II. Landscapes were initially selected and characterized using 1:50000 aerial photographs taken in 1996 (National Air Photo Library of Canada). A spatial analysis program (Idrisi: Eastman 1997) and a 1991 satellite image of eastern Ontario (Russian MK-4: courtesy of The Ecosystem Management Section of Professional Services for Ontario Parks Canada. Dept. of Canadian Heritage) were used to ensure that the $2 \mathrm{~km}^{2}$ landscapes did not overlap.

A landscape size of $2 \mathrm{~km}^{2}$ was deemed sufficiently large for study because (1) Ovenbirds and Wood Thrush interact with the surrounding landscape by foraging occasionally outside of their 2 ha territories (Zach and Falls 1979. Holmes and Robinson 


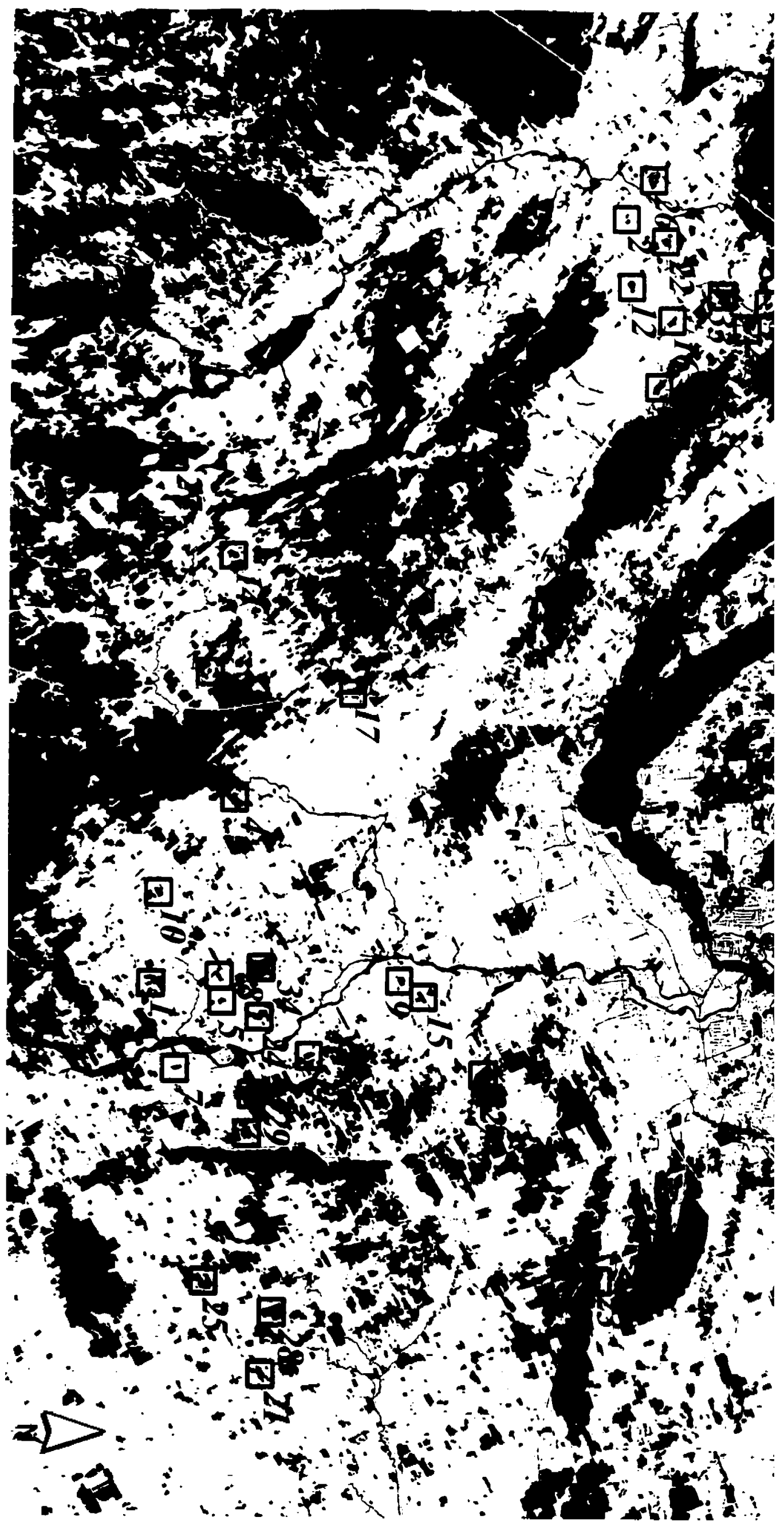


1988. Anders et al. 1998), and (2) a summary of mark-recapture studies for European and North American long distance migrants indicated that most marked individuals were recaptured within $200 \mathrm{~m}$ of their marked location. even after multiple breeding seasons (Villard 1991).

Similar studies have used larger scales ranging from $2.5-3 \mathrm{~km}^{-}$(McGarigal and McComb 1995) to $78.5 \mathrm{~km}^{2}$ (Wenny et al. 1993) but these scales do not seem to be based on specific accounts of predator and parasite movements. or extra-territorial bird movements. It is acknowledged that the landscape dimensions in this study may not encompass important larger scale processes. and thus the power to detect landscape forest cover effects may be reduced.

Each study landscape was centered on a focal habitat patch or plot in which bird and vegetation surveys were conducted. Focal habitat patches were deciduous or mixed deciduous/coniferous forest types and set within a matrix of varying amounts of both agricultural land (primarily hay and untended pasture) and forest cover (deciduous or mixed deciduous/coniferous forests). Of the 34 landscapes. 31 were centred on isolated tocal patches. The remaining three landscapes were centred on a forest plot. instead of an isolated forest patch. due to a shortage of appropriately sized and isolated focal forest patches. A patch was defined as an area of forest separated from other forest by paved roads or clearings of greater than 10 metres. On average, however. surrounding forest Was almost $60 \mathrm{~m}$ from the focal forest patches.

Areas of the focal patches ranged from 2.96 ha to 122.70 ha. and were calculated from digitized topographic maps (based on 1984 - 1989 aerial photographs) using the 
spatial analysis programs Idrisi (Eastman 1997) and Fragstats (McGarigal and Marks 1994) (Table 2). Including both core and edge habitat, the smallest habitat patch was large enough to contain at least 1 territory of any individual of the study species. while the larger patches could contain more than 10 (Twomey 1945. Stenger 1958. Freemark and Collins 1992). Core areas were calculated using the same method as that used for patch area, and ranged from $0.59-84.16$ ha. Core area was defined as torest greater than $100 \mathrm{~m}$ from the forest boundary based on density and fledgling success thresholds found by Wenny (1989) and Gates and Gysel (1978). respectively.

Study landscapes were selected to represent a range of percent forest cover surrounding the focal patch (Figure 2). Landscapes were selected to minimize the correlation across landscapes between focal patch size and amount of forest in the landscape surrounding the patch. so that their relative importance could be estimated in the statistical analysis. A non-random selection of landscapes was necessary because patch size in random samples of real landscapes is expected to be correlated to the amount of surrounding forest cover. Because selection was subjective. landscapes do not necessarily retlect the true structure and configuration of the region. Others (e.g. Pearson 1993. McGarigal and McComb 1995. Trzcinski et al. 1999) have used this pseudo-experimental approach to site selection.

The amount of surrounding forest covering each study landscape ranged from 0 to 46.02 percent. with 10 of the 34 landscapes containing over 33 percent forest cover. The range was chosen to encompass a threshold found by Robbins et al. (1989) who determined that patch area effects decreased when the percent habitat cover within a 2$\mathrm{km}$ radius of the patch exceeded 33 percent. 
Table 2. Focal forest patch and landscape characteristics for each $2 \mathrm{~km}^{2}$ study landscape. Total forest cover is the sum of focal forest patch size and surrounding forest cover. Core area is calculated based on an edge width of $100 \mathrm{~m}$. See Figure 1 for geographical locations.

\begin{tabular}{|c|c|c|c|c|}
\hline $\begin{array}{c}\text { Site } \\
\text { Number }\end{array}$ & $\begin{array}{c}\text { Focal Patch } \\
\text { Area (ha) } \\
\end{array}$ & $\begin{array}{c}\text { Core Area } \\
\text { (ha) }\end{array}$ & $\begin{array}{c}\text { Surrounding forest } \\
\text { cover (\%) }\end{array}$ & $\begin{array}{c}\text { Total forest cover } \\
(\%)\end{array}$ \\
\hline 1 & 2.96 & 0.59 & 26.58 & 28.06 \\
\hline 2 & 5.30 & 2.23 & 2.51 & 5.16 \\
\hline 3 & 5.66 & 1.94 & +5.49 & 48.32 \\
\hline 4 & 8.35 & 3.59 & +5.42 & 49.60 \\
\hline 5 & 9.56 & +.12 & 4.38 & 9.16 \\
\hline 6 & 9.92 & 4.39 & 38.32 & +3.28 \\
\hline 7 & 10.52 & +.20 & 1.32 & 6.58 \\
\hline 8 & 10.83 & 5.07 & 6.70 & 12.11 \\
\hline 9 & 14.71 & 8.37 & 1.69 & 9.04 \\
\hline 10 & 15.42 & 8.84 & 9.73 & 17.44 \\
\hline 11 & 15.68 & 8.18 & 24.81 & 32.65 \\
\hline 12 & 15.73 & 9.37 & 5.02 & 12.89 \\
\hline 13 & 17.78 & 9.59 & 35.54 & 4.42 \\
\hline 14 & 19.68 & 11.07 & 20.87 & 30.71 \\
\hline 15 & 21.24 & 11.26 & 9.60 & 20.22 \\
\hline 16 & 21.82 & 13.84 & 6.85 & 17.76 \\
\hline 17 & $26 .+6$ & 14.73 & 30.51 & +3.74 \\
\hline 18 & 26.70 & 15.23 & 25.48 & 38.83 \\
\hline 19 & 29.34 & 18.74 & 19.47 & 34.14 \\
\hline 20 & 33.08 & 19.76 & +6.02 & 62.56 \\
\hline 21 & 34.24 & 18.21 & 1.84 & 18.96 \\
\hline 22 & 36.83 & 23.82 & 14.07 & 32.49 \\
\hline 23 & 42.67 & 30.20 & 35.02 & 56.35 \\
\hline 24 & 45.30 & 25.90 & 5.31 & 27.96 \\
\hline 25 & 45.42 & 29.62 & 8.04 & 30.75 \\
\hline 26 & 52.79 & 37.14 & 9.48 & 35.87 \\
\hline 27 & 57.25 & 34.86 & 44.05 & 72.68 \\
\hline 28 & 74.36 & 55.43 & 0.00 & 37.18 \\
\hline $29 *$ & 80.00 & 70.00 & 45.25 & 85.25 \\
\hline $30^{*}$ & 80.00 & 65.00 & +5.40 & 85.40 \\
\hline $31^{*}$ & 80.00 & 75.00 & $\$ 4.93$ & 84.93 \\
\hline 32 & 83.53 & 66.17 & 21.50 & 63.27 \\
\hline 33 & 87.20 & 63.60 & 31.09 & 74.69 \\
\hline 34 & 122.70 & 84.16 & 0.78 & 62.14 \\
\hline
\end{tabular}

* continuous forest landscapes 


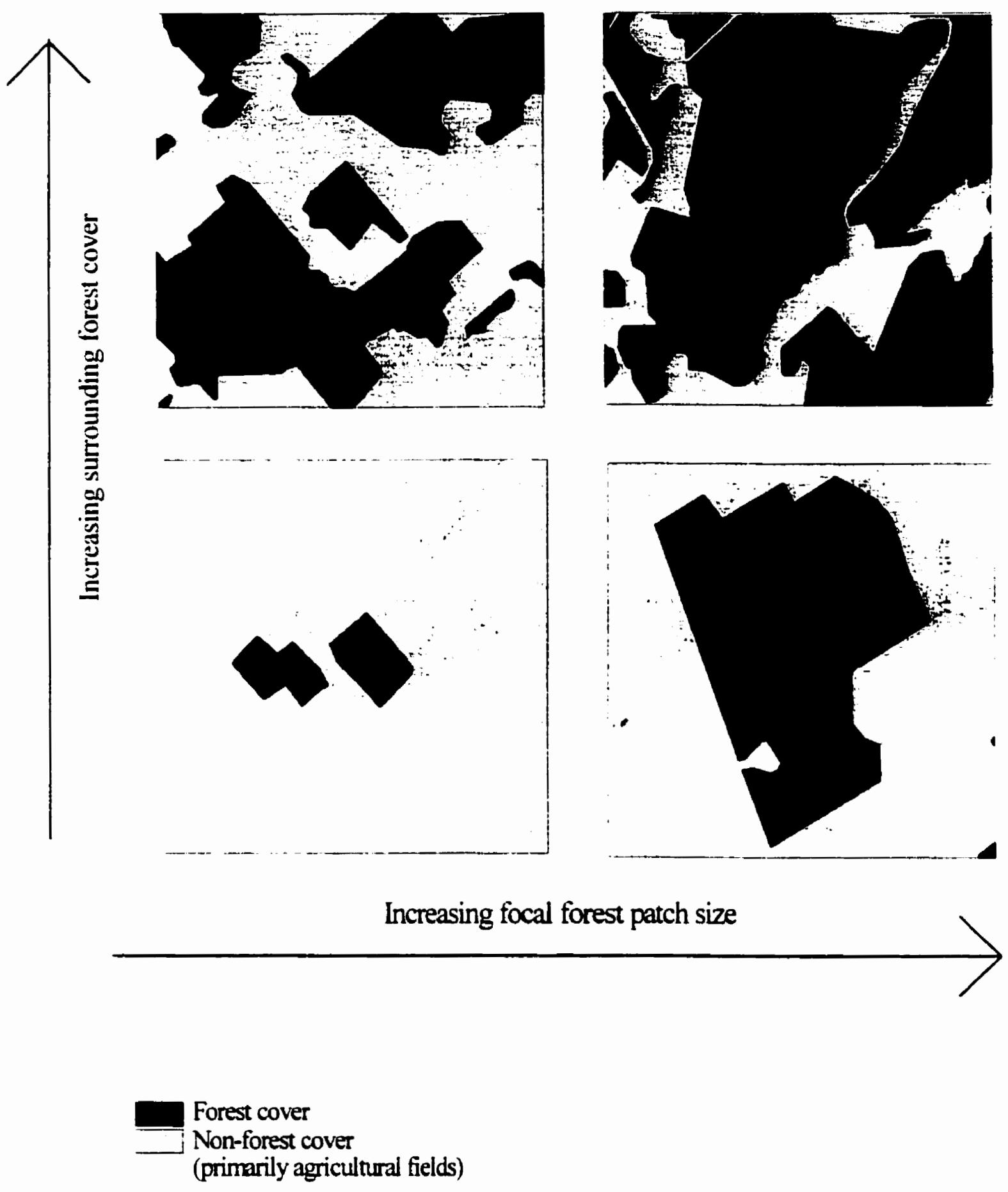

Figure 2. Representation of patch and landscape site selection. Study landscapes were selected to represent a range in percent forest cover surrounding the focal forest patch, such that the 2 variables were uncorrelated (inspired by Trzcinski et al. 1999). 
Since the surrounding landscape was defined as the land area outside of the focal patch, percent surrounding landscape forest cover (hereafter referred to as surrounding torest cover) was calculated by dividing the forested land area outside of a given patch by the total land area outside of the patch. Focal patch size was excluded from the calculation of surrounding forest cover so that it could not influence the estimation of surrounding torest cover.

Due to a shortage of naturally occurring landscapes characterized by both it large focal forest patch ( $>70$ ha) and a large amount of surrounding forest cover ( $>33$ percent) in the study region, 3 continuous forest landscapes were surveyed to simulate the effect of a large forest patch embedded in a high percent forest cover. A landscape was defined as continuous if the area of its focal forest patch exceeded $2 \mathrm{~km}^{2}$, and if most of the boundaries of the focal patch extended beyond those of the study landscape. Eighty ha at the centre of each of the 3 continuous forests were surveyed.

Even though continuous forests were larger than $2 \mathrm{~km}^{2}$. the sinuous configuration of certain sections of the forests allowed some non-forest land to be contained within the $2 \mathrm{~km}^{2}$ landscape. Therefore, percent landscape forest cover was calculated by subtracting the 80 ha of surveyed forest from the total amount of forest cover in the $2 \mathrm{~km}^{2}$ landscape and dividing that amount by the total landscape area surrounding the surveyed forest (in this case 120 ha). 


\section{BIRD SLRVEYS}

\section{.Male Density}

The focal forest patches in each landscape were surveyed comprehensively 3 times each between sunrise and 9:30am from May 18 to July 15. 1998. Survey time spent per ha was approximately equal across all focal forests. Total surveyed area within continuous torests was confïmed with topographic maps and aerial photographs.

Surveys of the focal torest patches were conducted sequentially to stagger them throughout the field season. Each pair of field assistants surveyed all patches at least once to prevent sampling bias. Surveys were conducted after May 18 to minimize the chance that birds detected were using the forest patch as a stopover point and not as a breeding site. An additional focal forest patch and landscape replaced patches in which none of the 3 study species was detected. Playbacks were used to verify absence of a target species, as well as to encourage singing in late mornings and poor weather.

The maximum abundance value recorded across all 3 visits was used as the best estimate of total male abundance in a given focal patch. This was based on the observation that the recorded abundance tended to drop with rainy, windy or cold weather. Thus it was assumed that fluctuations in the number of recorded birds were due primarily to differential detectibility (caused by variation in singing rates) rather than actual tluctuations in abundance. The maximum abundance value for each forest patch was divided by the focal patch size to obtain an estimate of male density. 


\section{Ovenbird Pairing Success}

Focal forest patches were surveyed from May 26 to July 6. 1998 to locate territorial male Ovenbirds and establish pairing status. Only 25 of the 34 forest patches were surveyed since 9 patches contained no Ovenbirds. Singing perches of male Ovenbirds were flagged to approximate territory location and to facilitate finding the perch again on subsequent visits. Paired males sing less trequently than unpaired males (Hann 1937. Lein 1980. Gibbs 1988. Van Horn 1990), and therefore playbacks were used to encourage singing in paired males and increase the chance that singing perches of both paired and unpaired males would be found with equal likelihood.

The paired status of male Ovenbirds was evaluated on 3 separate visits using singing rate and behaviour as indicators of status. Playbacks were also used occasionally to elicit responses by female mates suspected to be within a territory. However, because playbacks could potentially interfere with singing rates and behaviour of males. they were used only after singing rates and behaviour were recorded.

Paired status of males was evaluated for 20 minutes at each singing perch. At male was considered paired if he met 2 of the following 3 criteria: (1) low singing rate. (2) paired behavioural cues. and (3) tolerance of another Ovenbird within $5 \mathrm{~m}$. In the first 5 minutes of the 20 minute evaluation, singing rates of territorial male Ovenbirds were recorded. Gibbs (1988) showed through field studies that single territorial males tend to sing 6 or fewer times in 5 minutes, while paired males sing more frequently. This method has since been used and validated by Gentry (1989) and Van Horn (1990).

During the timing, and for an additional 10 minutes, behavioural and visual cues were observed to confirm Ovenbird pairing status, such as food carrying, presence of a 
female. 'tsip' sounds made by a non-singing Ovenbird (Lein. 1980), or discovery of a nest. In the final 5 minutes, song playbacks were used to encourage a response from any female within the territory. When a discrepancy was found between the status as determined by singing rates and status and determined by behaviour. the status based on behavioural observations was used.

Weather was expected to affect the singing frequency of male Ovenbirds. resulting in tewer detected males on windy or rainy days. and more detected males on sunny. still days. Therefore, the visit with the highest recorded number of males (regardless of paired status) was deemed to most accurately reflect the total number of males in the patch, and pairing status records for that day were used in the data analysis. In cases where the same total number of males was recorded on separate visits. the visit to be used for further analysis was randomly selected.

Because focal forest patches were each visited only 3 times, there were not enough registrations collected to adequately spot map individual territories (International Bird Census Committee 1970. Bibby et al. 1992). As a result, there is a risk that territorial Ovenbird males may have been double counted while moving around within their territories. This risk was minimized in each visit by only flagging the singing perches if they were no less than $100 \mathrm{~m}$ trom the next nearest singing perch. unless the songs originating from 2 close perches occurred simultaneously. Also, the low mean density of Ovenbird territories in this study ( 8 Ovenbirds per 100 ha) compared with reported average densities ( 14 per 100 ha - Whitcomb et al. 1981) facilitated the upproximate delineation of Ovenbird territories without spotmapping. 


\section{Data ANalysis}

\section{Density}

Stepwise regression analysis was used in SAS (SAS Institute 1990) to determine which landscape and habitat variables best predicted density of each target species. Predictor variables included in each stepwise regression were focal forest patch area. patch core area, surrounding landscape forest cover, and total landscape forest cover. In addition. those habitat variables that were significantly correlated with landscape variables were included in the stepwise regressions. Tree height, tree species richness and percent deciduous species were not included in the analysis due to missing data. The degree to which the 4 predictor variables were correlated was tested with a Pearson's correlation test to aid in the interpretation of the regression results and confirm the independence between the landscape scale and patch scale variables.

Core area. the presumed habitat of the target species, was included in the analysis to counter possible biases arising from a 'geometric effect' (Bender et al. 1998). The geometric effect predicts that densities of interior-habitat specialists will be underestimated in small habitat patches if patch area. rather than inhabited area (patch core area), is used in the analysis. Total forest cover was included to determine whether it had a greater effect than its constituent parts: patch size and surrounding forest cover. Total forest cover and surrounding forest cover differ because the former includes the focal patch. and the latter is only the percent of forest cover in the landscape outside the focal patch.

A linear regression model was used to describe the relationship between Ovenbird density and the predictor variable and a log transformation of the dependent 
variable allowed for regression assumptions to be met. A negative power function was required to improve the fit of and meet regression assumptions for the Red-eyed Vireo density model. A stepwise regression analysis was not used for Wood Thrush due to violations of regression assumptions in the residuals that could not be remedied with dependent variable transformations. As a resuit. a Spearman's rank correlation test was used to describe the relationships between Wood Thrush density and the landscape. patch and habitat variables.

The conventional statistical tests used in this study to analyse the relationship between bird density (N/A) and patch size (A) do not account for the lack of independence between the two variables. If abundance $(N)$ and area are both random variables, and if the variance of area is greater than the variance in abundance. then an inverse relationship between density and area would likely result (Currie pers. comm.). Improved statistical analyses that account for this problem are recommended for future research. and the following results based on conventional analysis methods should be interpreted with care.

\section{Pairing success}

Ovenbird pairing success data were evaluated with a logistic stepwise regression using the same predictor variables as those used in the density regression analysis. The total number of Ovenbirds detected in a focal forest patch were considered 'trials'. while the number of paired individuals within that patch were considered 'successful events'. Pairing success ratios in the 3 continuous forests were also compared to pairing success ratios in the patches using a t-test for unequal variances. A t-test was conducted in 
addition to the regression because it allowed for comparisons between this paper and others that compare conditions in extensive forests to patches.

Because nests within territories in small patches have a higher chance of failure (Burke. 1998). female Ovenbirds may abandon nests and move to new territories (e.g. territories within larger patches) after an unsuccessful breeding attempt. Thus pairing status of males in small patches ( $<70$ ha) may decrease over the breeding season as a result of females leaving to find other territories. while the pairing status of males in large patches (> 70 ha) may increase. A linear regression was used to determine whether the pairing success ratio changed over the breeding season differentially for small and large forest patches. Pairing status records for all three site visits were used in this analysis to determine if changes in pairing ratios corresponded with patch size. A time series regression may have been more appropriate since it corrects for the autocorrelation in the variable time. and thus results should be interpreted with care. 


\section{RESUlts}

\section{Within-PATCH (HABITAT) CHARACTERISTICS}

Tree density was correlated with focal patch area $\left(R^{2}=0.19 . P=0.01\right)$ and core area $\left(R^{2}\right.$ $=0.19 . p=0.01)$. while diameter at breast height $(\mathrm{DBH})$ was significantly correlated with surrounding forest cover $\left(R^{2}=0.11, p=0.05\right)$.

\section{Patch and Landscape Characteristics}

Landscapes varied greatly in both focal patch area and landscape forest cover (Table 2). As designed (see methods). focal forest patch area and surrounding forest cover were not correlated (Table 3). Core area and surrounding forest cover were also not correlated. As expected. total forest cover was correlated to surrounding forest cover. focal patch area and core area.

\section{BIRD SLRVEYS}

\section{Summary statistics}

In all. 117 Ovenbirds. 115 Red-eyed Vireos. and 48 Wood Thrushes were detected in focal forest patches across the 34 landscapes (Table 4). Red-eyed Vireos were found in almost all of the focal patches/plots ( 32 of 34 patches/plots) while Ovenbirds and Wood Thrush were only recorded in 26 and 19 of the 34 patches. respectively. Considerable variation existed in the numbers of birds detected per forest patch. 
Table 3. Pearson's correlation coefficients for landscape and patch variables.

\begin{tabular}{lccccc}
\hline & & PATCH & CORE & TOT & SURR \\
\hline \hline PATCH & $\mathrm{r}$ & 1.000 & & & \\
& & & & & \\
CORE & $\mathrm{r}$ & 0.984 & 1.000 & & \\
& $\mathrm{p}$ & 0.0001 & & & \\
& & & & & \\
TOT & $\mathrm{r}$ & 0.716 & 0.752 & 1.000 & 1.000 \\
& $\mathrm{p}$ & 0.0001 & 0.0001 & & \\
& & & & 0.777 & \\
SURR & $\mathrm{r}$ & 0.117 & 0.181 & 0.0001 & \\
& $\mathrm{p}$ & 0.510 & 0.303 & & \\
\hline
\end{tabular}

PATCH - Focal torest patch or plot area

CORE - Focal torest patch or plot core area (area of forest $>100 \mathrm{~m}$ from forest edge) TOT - Total amount of forest cover in the $2 \mathrm{~km}^{2}$ landscape (including focal patch/plot) SLRR - Total amount of forest cover in the $2 \mathrm{~km}^{2}$ landscape surrounding the focal patch/plot ti.e. excluding the focal patch/plot) 
Table 4 . Summary statistics of bird abundance and density based on maximum number of territorial male detections per patch for Ovenbird. Wood Thrush and Red-eyed Vireo. Standard deviations are indicated in brackets.

Ovenbird

mean no. individuals

detected per survey

mean density per ha

total detected

number of the $3+$ focal

patches/plots in which

species were detected

$0.12(0.14)$

117

26
Wood Thrush

$3.4(3.29) \quad 1.41(1.58)$

48

19
115

32

$3.38(2.74)$

$0.14(0.13)$ 


\section{Density}

A stepwise regression indicated that surrounding forest cover best predicted Ovenbird density $(F=5.88, p=0.02$. d.t. $=33)$ (Figure 3$)$ although the amount of variation in density explained by surrounding forest cover was low $\left(R^{2}=0.16\right)$. Since the effect of surrounding torest cover on Ovenbird density appeared to be driven by one point. an influence diagnostics analysis was conducted. No intluential data points were detected. Additionally, a Spearman's rank correlation test verified the significance of the relationship. Forest patch area, core area and habitat variables were not significant predictors of Ovenbird density.

Patch area was the best predictor of Red-eyed Vireo density. and the relationship was negative $\left(F=14.96, p=0.0005\right.$. d.f. $\left.=33 . R^{2}=0.32\right)$ (Figure 4). Landscape variables. core area. and habitat variables were not significant predictors of Red-eyed Vireo density. Wood Thrush density was only significantly correlated to patch area (Spearman $\left.R^{2}=0.12 . p=0.04\right)$. core area $\left(\right.$ Spearman $\left.R^{2}=0.12 \cdot p=0.04\right)$. and tree density (Spearman $R^{2}=0.29 . p=0.001$ ) (Figure 5a. b. c). 


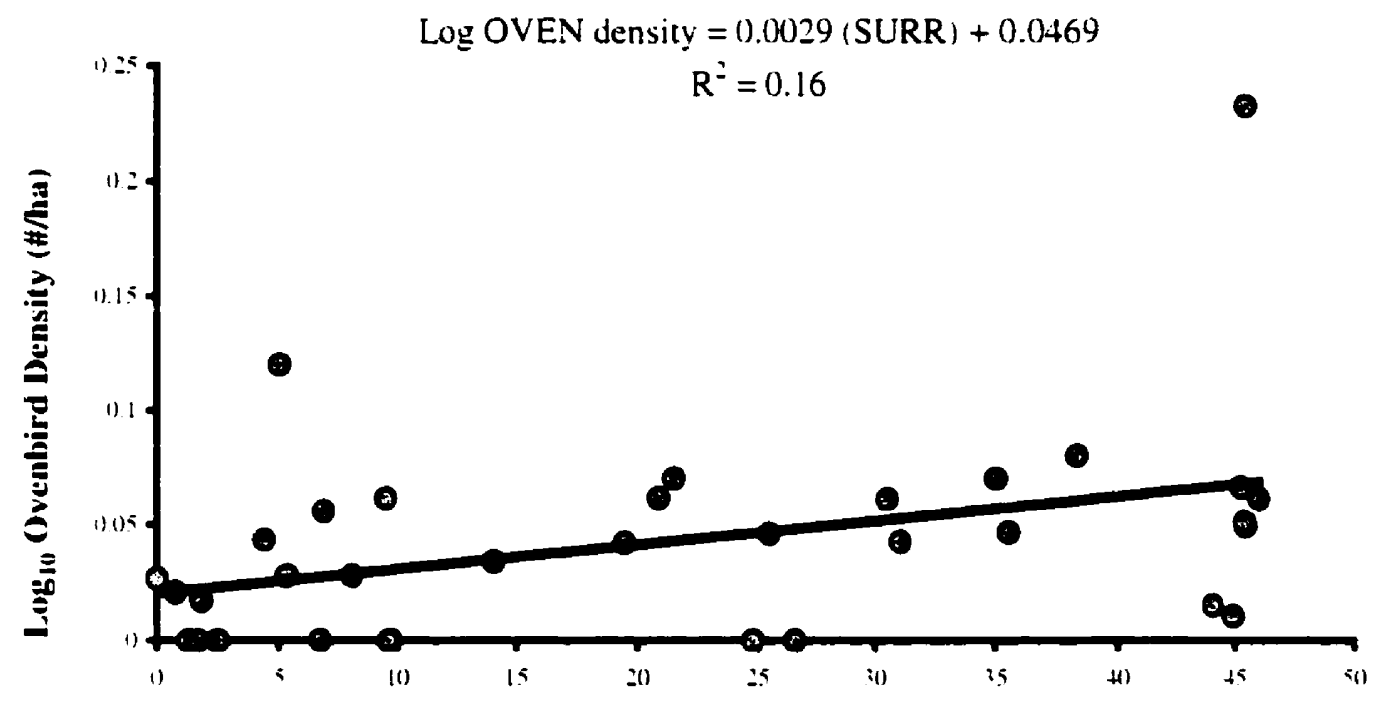

Percent Surrounding Forest Cover (SURR)

Figure 3. Relationship between male Ovenbird density in a focal forest patch/plots and proportion of forest cover in the surrounding $2 \mathrm{~km}^{2}$ landscape $(\mathrm{n}=34)$. 


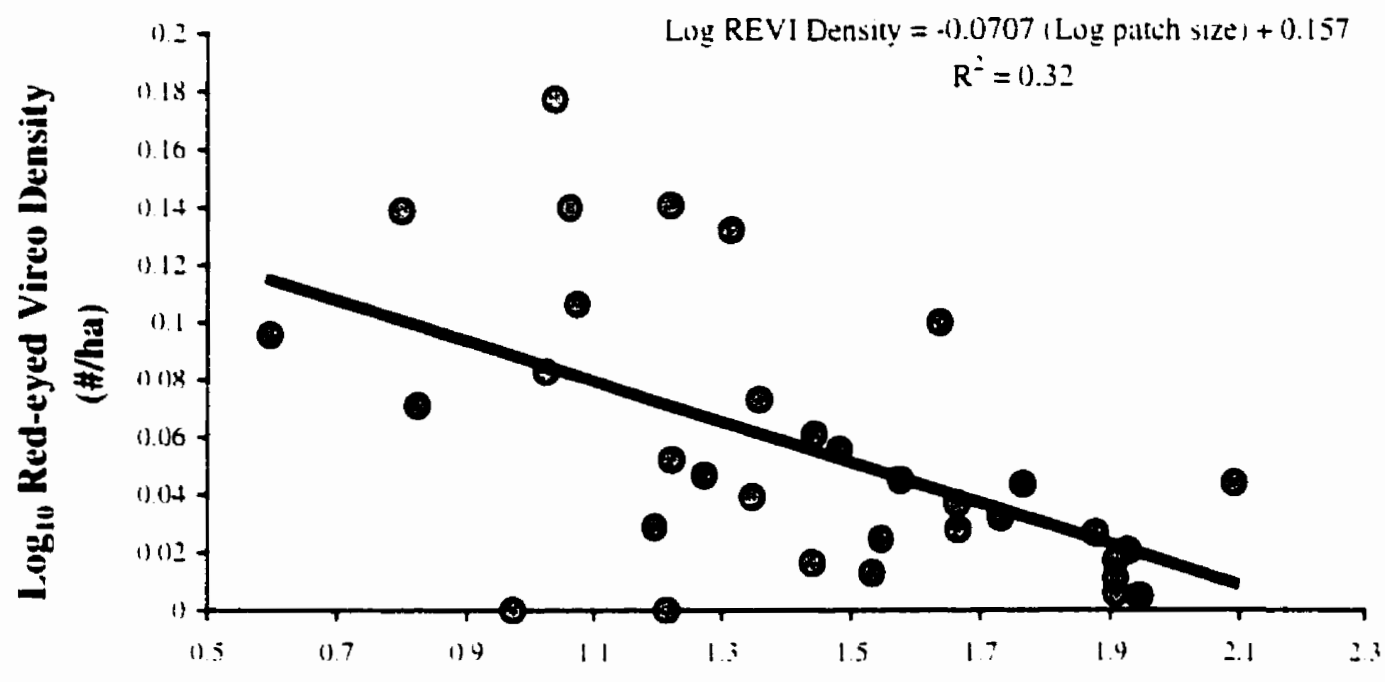

$\log _{10}$ Patch Size (ha)

Figure 4 . Relationship between male Red-eyed Vireo density and tocal forest patch/plot area $(n=34)$. 


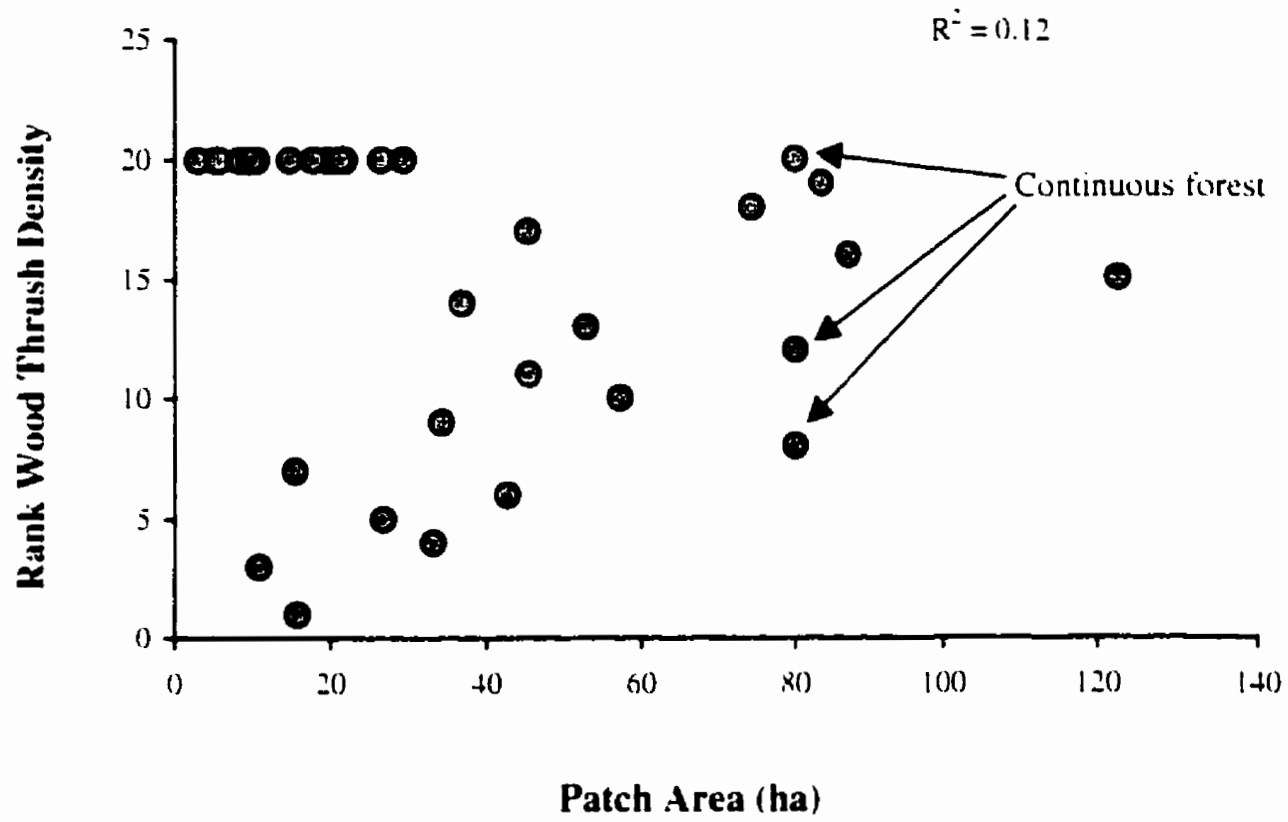

Figure 5a. Relationship between rank Wood Thrush density and patch/plot area $(n=34)$. 
$25-$

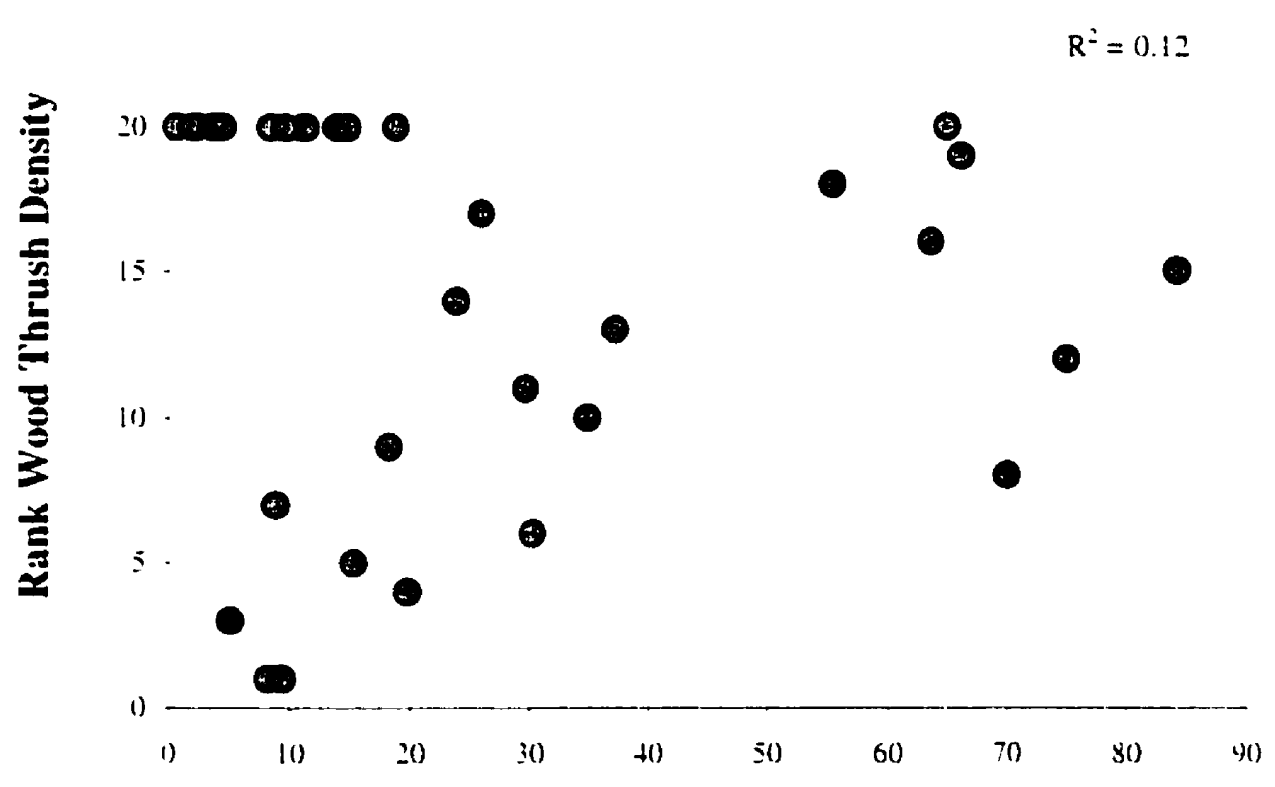

\section{Core Area (ha)}

Figure 5b. Relationship between Wood Thrush density and core area $(n=34)$. 


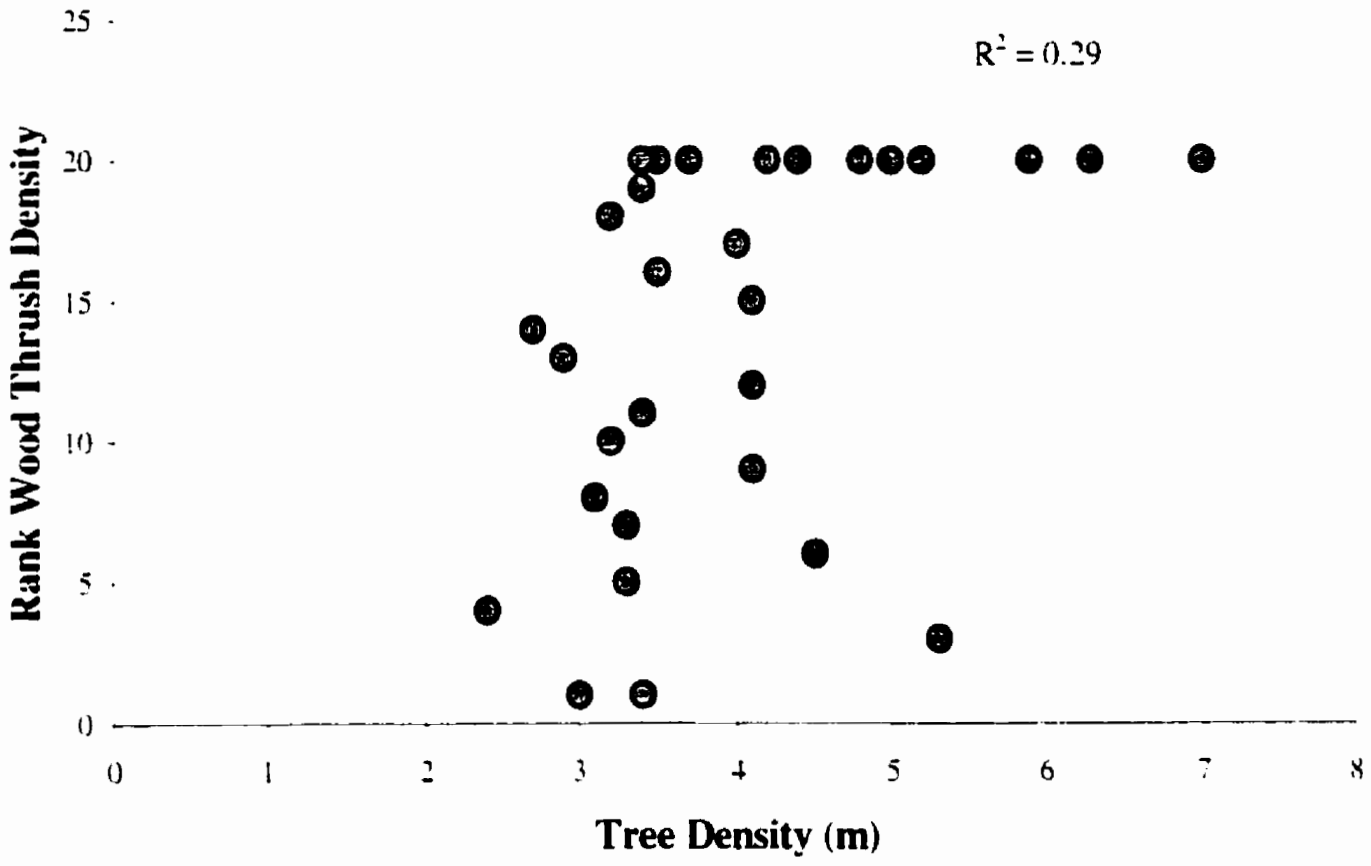

Figure 5c. Relationship between Wood Thrush density and tree density ( $n=34$ ). 


\section{Pairing success}

Pairing success ratios did not change significantly over the breeding season for either small or large focal patches $(p>0.05)$. Therefore, use of the pairing success ratio corresponding to the day of maximum abundance was deemed appropriate. However. due to a lack of independence of pairing success with time, results of the analysis may be contounded.

Logistic stepwise regression results were not significant (Figure 6). Mean pairing success, however. was significantly higher in the three extensive forests than in the forest patches $(t=2.6 . d . t .=3 . p=0.04)($ Table 5. Figure 7$)$. 


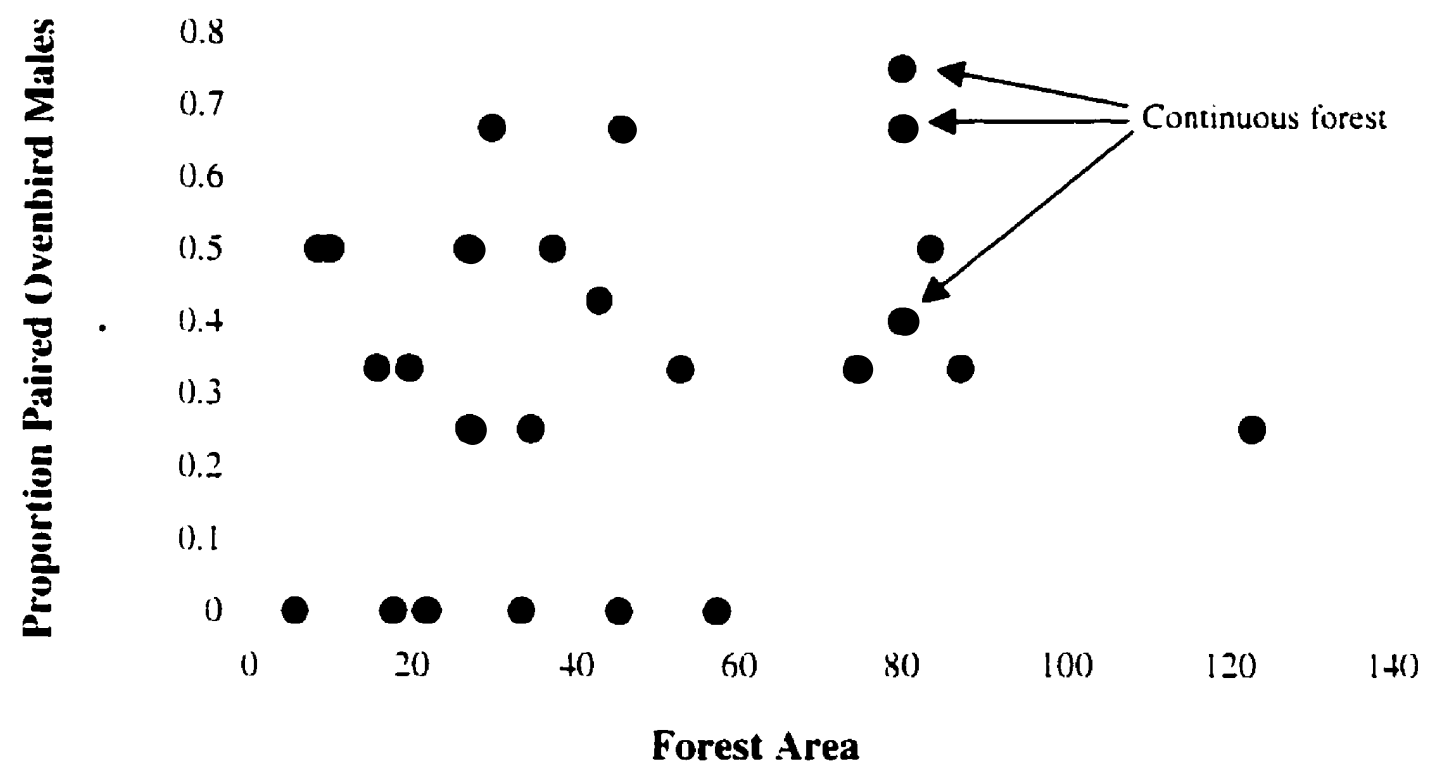

Figure 6. Relationship between male Ovenbird pairing success and focal forest patch area $(n=25)$. Regression results for this relationship were not significant $(p>0.05)$. 
Table 5. T-test comparison of Ovenbird pairing success in continuous iorests and torest patches.

\begin{tabular}{|c|c|c|}
\hline & Continuous forest & Forest patches \\
\hline Mean & 0.60 & 0.30 \\
\hline Variance & 0.03 & 0.05 \\
\hline \multirow[t]{2}{*}{ Observations } & 3 & 22 \\
\hline & $t=2.6$ & $p=0.04$ \\
\hline
\end{tabular}


Focal forest plots embedded in continuous forest. $\mathrm{n}=3$
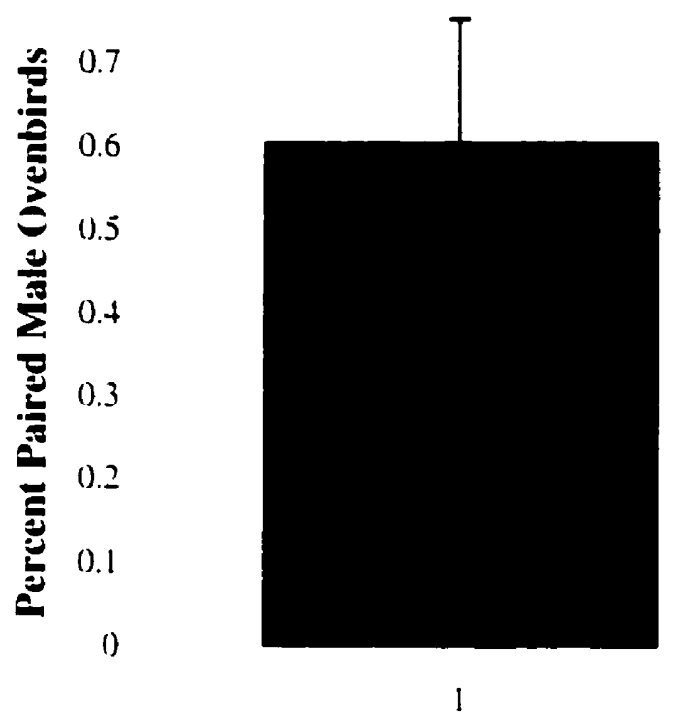

Focal forest patches. $\mathrm{n}=22$

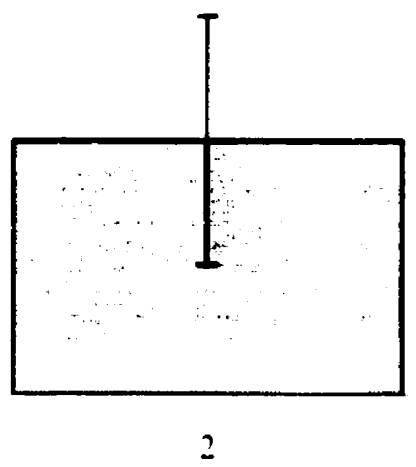

\section{Forest Size}

Figure 7. Difference in pairing success between 22 forest patches and 3 continuous forests. Bars represent one standard error from the mean. 


\section{Discussion}

The relationships found between density and patch size may be contounded since they do not account for the inherent. artefactual relationship between density and patch size caused by the use of patch size in the calculation of density (density = abundance/patch size). Relationships between density and non-patch variables such as surrounding forest cover and vegetation. however. should not be affected by this statistical relationship. Improved methods to analyze density data are strongly recommended for future studies.

\section{OvENBIRD DeNSITY}

Proportion of forest cover in the landscape surrounding a forest patch was the best predictor of Ovenbird density when compared with patch size, core area or habitat characteristics. The greater importance of landscape forest cover on Ovenbird density contrasts with previous reports which stress core area or patch area as the dominant predictor of bird density (e.g. Freemark and Collins 1992. Burke 1998. Bender et al. 1998).

The relationship between Ovenbird density and landscape forest cover seems strongly influenced by one site (site 3 ), however an analysis of the each point's influence did not identify site 3 as an influential observation. The relationship still remains marginally significant $(p=0.08)$ when site 3 is removed from the analysis. Removal of the second most influential site (site 7) restored the relationship's significance. In addition. a Spearman's rank correlation test confirmed the significant relationship between density and surrounding landscape forest cover. Almost 100 ha of contiguous 
forest encompass site 3 on all sides. whereas most focal forest patches were enclosed only partially by patchy forest cover. Due to the configuration of surrounding forest cover in this landscape, Ovenbirds may be more likely to cross nonforest habitat to reach the focal patch than they would in the other landscapes.

Contrary results between this and past empirical studies may be due to differences in study design. By ensuring independence between forest patch area and landscape forest cover. and by including a large range in landscape forest cover. this study may be better able to detect landscape effects. Dimensions of the relatively smallscale landscapes used in this study were based on bird movement data. and as a result. may be more appropriate to detect landscape relationships than the larger landscapes with arbitrary dimensions used in other studies (e.g. Wenny et al. 1993. Van Horn 1995). In addition. the species-specific design of this study is necessary to detect variation in responses for different species. which may not be detected by analysing bird assemblages or guilds.

Patch size effects may also be weaker in this study compared with other studies (Wander 1985. Gibbs and Faaborg 1990. Wenny et al. 1993) because of regional differences between study areas (but see Villard et al. 1993). Geographic location of a study has been shown to significantly affect bird density (Villard et al.1993). which may reflect differences in regional forest cover that exert control over patch level effects. Higher regional forest cover in the Ottawa region compared with Missouri and New Jersey may reduce patch size effects in this study when compared with others. 


\section{RED-EYED VIREO DENSITY}

Patch size best predicted Red-eyed Vireo density; however. the relationship was negative. Other research suggests no effect of patch size (Burke 1998) or a positive etfect (Hayden et al. 1985, summarized by Freemark et al. 1995) on Red-eyed Vireos. Since survey time was approximately equal per ha across all patch sizes. it is unlikely that small patches were more extensively sampled than large patches or continuous forest plots.

In contrast to the findings of many local studies. US Breeding Bird Survey (BBS) data indicates that Red-eyed Vireos have experienced a significant widespread population increase from 1966 to 1992. In light of the increasing trend and this study's results. Red-eyed Vireos may not be as sensitive to forest fragmentation and loss as previously thought. Red-eyed Vireos may be positively affected by an increase in the proportion of edge habitat associated with smaller patch size.

Since pairing status :was not evaluated for this species. it is unclear whether small patches had similar pairing success ratios when compared to pairing success ratios in larger patches. If Red-eyed Vireo males experience lower pairing success in small patches due to female preference for territories within large patches. the small patches in this study may support low breeding success and therefore may be population sinks. Thus male density. considered in isolation. may be a misleading indicator of habitat suitability.

Similarly. if Red-eyed Vireos are more susceptible to nest predation and parasitism in small patches as predicted by previous studies. the small patches of this study may be operating as population sinks by concentrating nests in areas of high risk 
and increasing density dependent nestling mortality. A similar result was reported by Gates and Gysel (1978) who found that certain bird species were present in habitat edges, despite their higher fledgling mortality there

\section{WOOD ThrLSh DENSITY}

Wood Thrush density was more closely associated with patch and microhabitat characteristics than landscape structure. Patch size and core area were each correlated to Wood Thrush density with almost equal strength and significance. However, since the correlation between Wood Thrush density and patch size may simply be an artifact of increased rate of habitat loss in smaller patches (geometric effect, where "habitat" is defined as forest core). core area is probably a more biologically meaningful predictor of density. Other research also indicates that core area best predicted Wood Thrush density (e.g. Hayden et al. 1985. Burke 1998).

\section{INTERSPECIFIC DIFFERENCES}

Responses of species to landscape structure have been shown to be individualistic in this study and others (Pearson 1993. Hinsley et al. 1995. McGarigal and McComb 1995. Jokimaki and Huhta 1996. Burke 1998. Saab 1999). Target species in this study responded very differently to patch area , core area and surrounding forest cover despite their relatively similar area-sensitive classifications and habitat requirements. Others have found that certain avian groups (managed forest species, habitat generalists and edge species) were more affected by landscape features than were other groups (Jukimaki and Huhta 1996). 
Differential responses between species or guilds may be due to differences in their life history traits. As ground nesters, Ovenbirds may be more susceptible to predation-related mortality and brood failure (Gibbs and Faaborg 1990. Villard et al. 1993) that tend to be lower in highly forested landscapes (Donovan et al. 1997). Thus Ovenbirds may experience either higher mortality in highly deforested landscapes. or they may have developed behaviour required to avoid such high risk landscapes.

Ovenbirds are classified as interior species which reflects their greater sensitivity to torest edge effects when compared to interior-edge species such as Red-eyed Vireos and Wood Thrush. A concurrent study using the same focal forest patches indicated that no Ovenbird territories were located within $50 \mathrm{~m}$ of the forest boundary (Swan 1999). Since edge effects may be moderated by landscape forest cover, Ovenbirds may be more sensitive to landscape forest cover than the other target species. However. a hypothesis based on edge sensitivity is not supported by this study's results since core area did not explain a significant amount of the variation in Ovenbird density.

\section{OVenbird PaIRINg Success}

Ovenbird males were more often paired in plots within continuous forests than in forest patches. but pairing success within both patches and plots did not differ in relationship to surrounding forest cover. No significant. gradual increase in pairing success occurred with increasing forest patch size. possibly because of an area threshold that was not encompassed by this study's range in patch sizes. A steeper slope for pairing success may have been noted if larger continuous forests were surveyed in this study. 
The relationship found between Ovenbird pairing success in continuous plots vs. forest patches is similar to findings by others. Gibbs and Faaborg (1990). Wander (1985) and Villard et al. (1993) found mean pairing success ratios to be around 80 percent for extensive forests (compared with $60 \%$ in this study), and between 23.5 and 58.6 for forest parches (compared with $30 \%$ in this study) (Villard et al. 1993).

Since nonbreeding temales are assumed not to exist (e.g. see Gibbs and Faaborg 1990. Villard et al. 1993), the high proportion of unmated males in all forests surveyed in this study suggests an uneven sex ratio. Additionally, results from this study do not support the hypothesis that females move preferentially from territories in small forest patches to territories in larger patches throughout the breeding season. Thus. unpaired males likely maintain their unpaired status throughout the breeding season. regardless of the size of patch they occupy.

Effects outside of breeding habitat such as greater female overwintering or migration mortality may cause the biased sex ratio. Female Ovenbirds overwinter in different locations and migrate at different times than males, and therefore they may be subjected to specific geographic or temporal stresses that males avoid. However, such external factors that reduce the female to male ratio only explain the existence of unpaired males in all torest patches: they do not account for the significant difference in the proportion of unpaired males between small patches and continuous forest.

Possible explanations for the greater proportion of unpaired males in forest patches compared with continuous forests include: (1) higher susceptibility of ground nesting female Ovenbirds in patches to mortality related predation (Gibbs and Faaborg 1990), (2) direct female selection of high quality territories, which are more likely to 
occur in large forests. (3) selection by females of older males who, in turn exclude younger males from premium territories. which are more likely to occur in large forests. or $(4)$ female selection of forests with higher male density (conspecific attraction) (Villard et al 1993). The conspecific attraction hypothesis does not adequately explain the disparity in pairing success ratios among forest sizes in this study. since density in extensive forests and patches were not significantly different.

\section{Ovenitidd Density Versles Pairing Success}

Ovenbird density and pairing success were each affected by habitat structure at different scales. This may be due to the behaviours or mechanisms driving density and pairing success and the scales at which they occur. While density may be driven by landscape scale mechanisms, such as dispersal/movement. foraging opportunities or predator density in a landscape, pairing success may be driven by smaller scale processes such as mate or territory selection.

For example, the density of birds within a forest patch relies. in part. on the ease with which that forest patch can be detected and reached by dispersing Ovenbirds. Because Ovenbirds are forest specialists who may be reluctant to cross non-torest gaps. the probability of reaching a forest patch may rely on the amount of habitat in a landscape. Forest patches in highly forested landscapes may be more easily reached by dispersing Ovenbirds, and thus density in those patches may be higher.

High Ovenbird density in forests surrounded by a high proportion of forest cover may also be because of greater foraging opportunities in nearby forests outside of the focal patch - particularly if the patch is small like most of those studied in this paper. 
Ovenbirds have been shown to forage beyond their 1-2 ha territories (Zach and Falls [979), which suggests that foraging opportunities may be a limiting factor for density. Local predator density may also diminish in highly forested landscapes, thereby reducing predation even in small forest patches and forest edges. Low density in patches within low forest cover landscapes may be the result of higher mortality; however, this would likely cause a notable decrease in density over the breeding season that was not found in this study.

Most existing hypotheses for the disparity in pairing success between small patches and large. continuous forests are based on patch scale mechanisms (e.g. Villard et al 1993). Female Ovenbirds may prefer territories located within large forests because of the greater proportion of interior habitat. and the greater average distance of territories from the forest edge. Females may use patch size as an indirect measure of the habitat quality through greater foraging opportunity. since invertebrate abundance increases in large forests (Burke and Nol 1998b).

There have been few studies that assess the relative importance of different scales on avian populations. and therefore few studies with which this one can be compared. For example. Van Horn et al. (1995) found that her smallest forest patch contained the highest density of Ovenbirds. She reasoned that it may be because that patch was the least isolated of the patches studied, and had a low interior to edge ratio. However, the patch was also surrounded by a high percent forest cover $(46 \%)$ and thus it is unclear whether their high density is due to patch quality or the surrounding landscape. More work is required to determine the scales at which density and pairing success are most influenced by habitat amount. 


\section{CONSERVATION IMPLICATIONS}

The amount of surrounding forest cover in a landscape, in addition to patch size. is important for the conservation of bird species. Saab (1999) found that landscape structure was the most important predictor for the occurrence of most species studied in riparian habitat patches. The majority of species studied by Hinsley et al. (1995) were significantly affected by landscape structure. although the independent effects of patch and landscape variables were not assessed. Lastly, the type of matrix surrounding small forest patches can dictate the types of bird communities found within those patches ISisk 1997).

The growing empirical evidence for the importance of surrounding landscape on forest bird communities lends support to the theory that forest reserves do not operate in isolation from the surrounding matrix: the structure and composition of a matrix surrounding a forest reserve affects the biological processes within. Additionally. despite the importance of patch size for many species. reserve design that is based on patch size and interpatch distance alone may be exclusionary for some species. Given the difficulty of preserving patches large enough to support viable populations. effective reserves design can not occur without considering the surrounding landscape, and urban and landscape planning should not be conducted without due consideration of their potential impact on proximal nature reserves.

Current attempts to minimize adverse effects of development on adjacent nature reserves are not adequate since avian populations within forest patches are affected by matrix structure over a kilometre away. Future research should not only be focused on clarifying the relationship between scale and avian species. it should also test for the 
independent effects of different matrix types such as urban areas, forest clearcuts. and various agricultural uses on avian assemblages. 


\section{REFERENCES}

Anders. A. D.. J. Faaborg, and F. R. Thompson III. 1998. Postfledgling dispersal. habitat use and home-range size of juvenile Wood Thrushes. Auk 115:3+9-358.

Andren. H. 1992. Corvid density and nest predation in relation to forest fragmentation: a landscape perspective. Ecology 73:794-804.

Andren. H. 1994. Effects of habitat fragmentation on birds and mammals in landscapes with different proportions of suitable habitat: a review. Oikos 71:355-366.

Anglestam. P. 1992. Conservation of communities - the importance of edges. surroundings and landscape mosaic structure. Pages 9-70 in Hansson, L., editor. Ecological Principles of Nature Conservation. London: Elsevier.

Askins. R. A. and M. J. Philbrick. 1987. Effect of changes in regional forest abundance on the decline and recovery of a forest bird community. Wilson Bulletin 99:7-21.

Askins. R. A.. Lynch. J.F.. and Greenberg. R. 1990. Population declines in migratory birds in eastern North America. Current Ornithology 7:1-57.

Bender. D. J., T. A. Contreras, and L. Fahrig. 1998. Habitat loss and population decline: a meta-analysis of the patch size effect. Ecology 79:517-533. 
Bibby. C. J.. N. D. Burgess. and D. A. Hill. 1992. Pages 58.66-84 in Bird Census Techniques. Academic Press Ltd., London.

Blake. J. G. 1991. Nested subsets and the distribution of birds on isolated woodlots. Conservation Biology 5:58-66.

Blake. J. G and J. R. Karr. 1987. Breeding birds of isolated woodlots: area and habitat relationships. Ecology 68:1724-1734.

Boecklen, W. J.. and N. J. Gotelli. 1984. Island biogeography theory and conservation practice: species-area or specious-area relationship? Biological Conservation 29:63-80.

Bolger. D. T.. A. C. Alberts and M. E. Soule. 1991. Occurrence patterns of bird species in habitat tragments: sampling. extinction. and nested species subsets. American Naturalist 132:155-166.

Bollinger. E. K., B. D. Peer, and R. W. Jansen. 1997. Status of Neotropical migrants in three forest fragments in Illinois. Wilson Bulletin 109:521-526́.

Bond. R. R. 1957. Ecological distribution of breeding birds in the upland forests of southern Wisconsin. Ecological Monographs 27:351-384. 
Brawn. J. D. and S. K. Robinson. 1996. Source-sink population dynamics may complicate the interpretation of long-term census data. Ecology 77:3-12.

Brown. J. H. 1984. On the relationship between abundance and distribution of species. American Naturalist 124:255-279.

Brittingham. M.C. and S.A. Temple. 1983. Have Cowbirds caused forest songbirds to decline'? Bioscience 33:31-35.

Bruederle. L. P. and F. W. Stearns. 1985. Ice storm damage to a southern Wisconsin mesic forest. Bulletin of the Torrey Botanical Club 112:167-175.

Burke. D.M. 1998. The relationship between forest fragmentation. food abundance, nest site. habitat and reproductive success of forest breeding birds. Ph.D. Thesis. Trent University. Peterborough.

Burke. D. M. and E. Nol. 1998a. Edge and fragment size effects on the vegetation of deciduous forest in Ontario. Canada. Natural Areas Journal 18:45-53.

Burke. D. M. and E. Nol 1998b. Influence of food abundance. nest-site habitat and forest fragmentation on breeding Ovenbirds. Auk 115:96-104. 
Connor. E.F. and E. D. McCoy. 1979. The statistics and biology of the species-area relationship. American Naturalist 1 13:791-833.

Canadian Wildlife Service (CWS). 1998. Bird Trends. No. 6. Migratory Birds Conservation Division. Canadian Wildlife Service. Ottawa. ON.

DeCalesta. D. S. 1994. Effect of white-tailed deer on songbirds within managed forests in Pennsylvania. Journal of Wildlife Management 58:711-718.

Donovan. T.M.. F.R. Thompson III.. J. Faaborg, and J.R. Probst. 1995. Reproductive success of migratory birds in habitat sources and sinks. Conservation Biology 9:13801395.

Donovan. T.M.. P.W. Jones. E.M. Annand. and F.R.Thompsun III. 1997. Variation in local-scale edge effects: mechanisms and landscape context. Ecology 78:2064-2075.

Eastman. R. J. 1997. Idrisi for Windows: user’s guide. Version 2.0. Clark University. Massachusetts.

Fahrig. L. and G. Merriam. 1994. Conservation of fragmented populations. Conservation Biology 8:50-59. 
Fahrig. L. and A.A. Grez. 1996. Population spatial structure, human-caused landscape changes and species survival. Revista Chilena de Historia Natural 69:5-13.

Fahrig. L. 1997. Relative effects of habitat loss and fragmentation on population extinction. Journal of Wildlife Management 61:603-610.

Forman. R. T. T.. A. E. Galli. and C. F. Leck. 1976. Forest size and avian diversity in New Jersey woodlots with some land use implications. Oecologia 26:1-8.

Freemark. K.E. and B. Collins. 1992. Landscape ecology of birds breeding in temperate forest fragments. Pages $+43-454$ in Hagan III. J. M. and D.W. Johnston. editors. Ecology and conservation of Neotropical migrant landbirds. Smithsonian Institution Press. Washington D.C.

Freemark. K. E. and H.G. Merriam. 1986. Importance of area habitat heterogeneity to bird assemblages in temperate forest fragmentation. Biological Conservation 36:115141.

Freemark. K. E.. J. B. Dunning, S. J Hejl, and J. R. Probst. 1995. A landscape ecology perspective for research conservation and management. Pages $381-427$ in Martin. T. E. and D. M. Finch. editors. Ecology and management of Neotropical migratory birds: a synthesis and review of critical issues. Oxford University Press, New York. 
Gates. J. E. and L. W. Gysel. 1978. Avian nest dispersion and fledgling success in fieldtorest ecotones. Ecology 59:871-883.

Galli. A. E.. C. F. Leck. and R. T. T. Forman. 1976. Avian distribution patterns in forest islands of different sizes in central New Jersey. Auk 93:356-364.

Gentry, R. 1989. Variable mating success of the Ovenbird (Seiurus aurocapillus) within remnant forest tracts of central Missouri. M.A. Thesis, Univ. Missouri, Columbia.

Gibbs. J. P. 1988. Forest fragmentation. mating success. and the singing behaviour of the Ovenbird (Seiurus aurocapillus) and Kentucky Warbler (Oporornis formosus) in central Missouri. M.A. Thesis. Univ. Missouri-Columbia.

Gibbs J. P. and J. Faaborg. 1990. Estimating the viability of Ovenbird and Kentucky Warbler populations in forest fragments. Conservation Biology 4:193-196.

Gustafson. E. J. and G. R. Parker 1992. Relationships between landcover proportion and indices of landscape spatial pattern. Landscape Ecology 7:101-110.

Haas. C. A. 1995. Dispersal and use of corridors by birds in wooded patches on an agricultural landscape. Conservation Biology 9:845-854. 
Hahn. D. C. and J. Hatfield. 1994. Parasitism at the landscape scale: Cowbirds prefer forests. Conservation Biology 9:1415-1424.

Haila, Y. 1983. Landbirds on northern islands: a sampling metaphor for insular colonization. Oikos 41:334-351.

Haila. Y. and I . K. Hanski. 1984. Methodology for studying the effect of habitat fragmentation on land birds. Annales Zoologici Fennici 21:393-397.

Hann. H.W. 1937. Life history of the Ovenbird in southern Michigan. Wilson Bulletin 44: 146-235.

Hanski. I. and D. Simberloff. 1997. The metapopulations approach. its history. conceptual domain. and application to conservation. in Hanski. I.A. and M. E. Gilpin. editors. Metapopulation biology. Academic Press. San Diego.

Hayden. T. J.. J. Faaborg, and R. L. Clawson. 1985. Estimates of minimum area requirements for Missouri forest birds. Transactions. Missouri Academy of Science. 19:11-22.

Hinsley. S. A.. P. E. Bellamy. I. Newton and T. H. Sparks. 1995. Habitat and landscape factors influencing the presence of individual breeding bird species in woodland fragments. Journal of Avian Biology 26:94-104. 
Holmes, R.T. and S.K. Robinson. 1988. Spatial patterns, foraging tactics, and diets of ground-foraging birds in a northern hardwoods forest. Wilson Bulletin 100:377-394.

Hoover. J. P.. M. C. Brittingham, and L. J. Goodrich. 1995. Effects of forest patch size on nesting success of Wood Thrushes. Auk 112:146-155.

International Bird Census Committee. 1970. Recommendations for an international standard for a mapping method in bird census work. Audoban Field Notes 24:722-726.

James. R.D., P.L. McLaren, and J. C. Barlow. 1976. Annotated Checklist of the Birds of Ontario. Life Sciences Miscellaneous Publications, Royal Ontario Museum.

Jokimaki. J. and E. Huhta. 1996. Effects of landscape matrix and habitat structure on a bird community in northern Finland: a multi-scale approach. Ornis Fennica. 73:97-113.

Lein. M. R. 1980. Display behaviour of Ovenbirds (Seiurus aurocapillus) I. non-song vocalizations. Wilson Bulletin. 92:312-329.

Levins. R. 1970. Extinction. Pages 77-107 in Gesternhaber. M.. editor. Some mathematical problems in biology. American Mathematicai Society, Providence, RI.

Lynch. J. F. and D. F. Whigham 1984. Effects of forest fragmentation on breeding bird 
communities in Maryland, USA. Biological Conservation 28:287-324.

MacArthur, R. H. and E. O. Wilson. 1967. The theory of island biogeography.

Princeton University Press. Princeton. New Jersey.

Mazerolle. M. J. and M.-A. Villard. 1999. Patch characteristics and landscape context as predictors of species presence and abundance: A review. Ecoscience 6:117-124.

McGarigal, K. and W. C. McComb. 1995. Relationships between landscape structure and breeding birds in the Oregon coast range. Ecological Monographs 65:235-260.

McGarigal. K. and B. J. Marks. 1994. Fragstats: spatial pattern analysis program for quantifying landscape structure. Version 2.0. Oregon State University, Oregon.

Merriam. G. 1984. Connectivity: a fundamental ecological characteristic of landscape pattern. Pages $5-15$ in Proceedings of the $1^{\text {st }}$ International Seminar on Methodology in Landscape Ecological Research and Planning. International Association for Landscape Ecology, Roskilde, Denmark.

Merriam. G. 1988. Landscape dynamics in farmland. Trends in Ecological Evolution 3:16-20. 
Paton, P. W. 1994. The effect of edge on avian nest success: how strong is the evidence? Conservation Biology 8:17-26.

Pearson, S. M. 1993. The spatial extent and relative influence of landscape-level factors on wintering bird populations. Landscape Ecology 8:3-18.

Porneluzi. P.. J. C. Bednarz. L. Goodrich. N. Zawada. and J. Hoover. 1993. Reproductive performance of territorial Ovenbirds occupying forest fragments and a contiguous forest in Pennsylvania. Conservation Biology 7:618-622.

Rebertus A. J., S. R. Shifley, R. H. Richards, and L. M. Roovers. 1997. Ice storm damage to an old-growth Oak hickory forest in Missouri. American Midland Naturalist 137:48-61.

Robbins. C. S. 1979. Effects of forest fragmentation on bird populations. Pages 198 212 in DeGraaf. R. M. and K. E. Evans, editors. Management of North Central and Northwestern forests for nongame birds. U.S. Dept of Agriculture. Forest Service. General Technical Report NC-5I.

Robbins. C. S.. D. K. Dawson. and B. A. Dowell. 1989. Habitat area requirements of breeding forest birds of the middle Atlantic states. Wildlife Monographs 103:6-34. 
Robinson. S. K. 1992. Population dynamics of breeding Neotropical migrants in a tragmented Illinois landscape. Pages $408+18$ in Hagan. J. M and D. W. Johnston. editors. Ecology and conservation of Neotropical migrant landbirds. Smithsonian Institution Press, Washington, D.C.

Rubinson. S. K.. F. R. Thompson III. T. M. Donovan. D. R. Whitehead. and J. Faaborg. 1995. Regional forest fragmentation and the nesting success of migratory birds. Science 267:1987-1990.

Roth. R. R.. M. S. Johnson. and T. J Underwood. 1996. Wood Thrush No. 246 in Poole. A. and F. Gill, editors. The Birds of North America. The Academy of Natural Sciences of Philadelphia.

Roth. R. R. and R. K. Johnson. 1993. Long-term dynamics of a Wood Thrush population breeding in a forest fragment. Auk 110:37-48.

Saab. V. 1999. Importance of spatial scale to habitat use by breeding birds in riparian forests: a hierarchical analysis. Ecological Applications 9:135-151.

Saunders. D. A.. R. J. Hobbs, and C. R. Margules. 1991. Biological consequences of ecosystem fragmentation. A review. Conservation Biology 5:18-32. 
SAS Institute. 1990. SAS/STAT user's guide, version $6.4^{\text {th }}$ edition. SAS Institute Inc.. Cary, North Carolina. USA.

Sisk. T. D 1997. Bird assemblages in patchy woodlands - modeling the effects of edge and matrix habitats. Ecological Applications 7:1170-1180.

Smith. T.M. and H.H. Shugart. 1987. Territory size variation in the Ovenbird: the role of habitat structure. Ecology 68:695-704.

Stenger. J. 1958. Food habits and available food of Ovenbirds in relation to territory size. Auk 75:335-346.

Swan. P. 1999. The Effect of Forest Edge on Male Ovenbird Territory Location and Pairing Success. Unpublished undergraduate thesis. Carleton University. Ottawa.

Temple. S.A. 1986. Predicting impacts of habitat fragmentation on forest birds: A comparison of two models. Pages $301-304$ in Verner. J., M. L. Morrison, and C. J. Ralph. editors. Wildlife 2000: Modeling Habitat Relationships of Terrestrial Vertebrates. Madison: University of Wisconsin Press.

Tewksbury. J. J.. S. J. Hejl. and T. E. Martin. 1998. Breeding productivity does not decline with increasing fragmentation in a western landscape. Ecology 79:2890-2903. 
Thompson. F. R. 1994. Temporal and spatial patterns of breeding Brown-headed Cowbirds in the Midwestern United-States. Auk 111:979-990.

Trzcinski. M. K.. L. Fahrig, and G. Merriam. 1999. Independent effects of forest cover and fragmentation on the distribution of forest breeding birds. Ecological Applications . 9:586-593.

Twomey. A.C. 1945. The bird population of an elm-maple forest with special reference to aspection, territorialism, and coactions. Ecological Monographs 15:173-205.

Van Horn. M.A. 1990. The relationship between edge and the pairing success of the Ovenbird (Seiurus aurocapillus). M.Sc. Thesis. University of Missouri. Columbia.

Van Horn. M. A.. R. M. Gentry. and J. Faaborg. 1995. Patterns of Ovenbird (Seiurus aurocupillus) pairing success in Missouri forest tracts. Auk 112:98-106.

Verboom. J.. A. Schotman. P. Opdam. and J. A. J. Metz. 1991. European nuthatch metapopulations in a fragmented agricultural landscape. Oikos 61:149-156.

Villard. M.-A. 1991. Spatio-temporal dynamics of forest bird patch populations in agricultural landscapes. Ph.D. Thesis, Carleton University, Ottawa. 
Villard. M.-A.. P.R. Martin. and C.G. Drummond . 1993. Habitat fragmentation and pairing success in the Ovenbird (Seiurus aurocapillus). Auk 110:759-768.

Villard. M.-A. 1998. On forest-interior species. edge avoidance. area sensitivity and dogmas in avian conservation. Auk 115:801-805.

Wander. S.A. 1985. Comparative breeding biology of the Ovenbird in large vs. fragmented forests: implications for the conservation of Neotropical migrant birds. Ph.D. diss., Rutgers University. Piscataway. New Jersey.

Wenny. D.G. 1989. Population density and area requirements of three forest interior warblers in central Missouri. M.A. thesis. University of Missouri-Columbia.

Wenny. D.G.. R.L. Clawson. J. Faaborg, and S.L. Sheriff. 1993. Population density. habitat selection and minimum area requirements of three forest interior warblers in central Missouri. Condor 95:968-979.

Whitcomb. R. F.. C. S Robbins. J. F. Lynch. B. L. Whitcomb. M. K. Klimkiewicz. and D. Bystrak. 1981. Effects of forest fragmentation on avifauna of the eastern deciduous forest. Pages 125-205 in Burgess. R. L.. and D. M. Sharpe, editors. Island dynamics in man-dominated landscapes. Springer-Verlag, New York. NY. 
Wiens. J. A. 1994. Habitat fragmentation: island vs. landscape perspective on bird conservation. Ibis 137:S97-S104.

Wilcove. D. S. 1985. Nest predations in forest tracts and the decline of migratory songbirds. Ecology 66:1211-1212.

Wilcove. D. S., C. H. McLellon, and A. P. Dobson. 1986. Habitat fragmentation in the temperate zone. Pages 237-256 in M. E. Soule editor. Conservation biology: the science of scaricty and diversity. Sinauer Assoc. Inc.. Sunderland, M.A.

Wilcove, D. S. and S. K Robinson. 1990. The impact of forest fragmentation on bird communities in eastern North America. Pages 319-331 in Keast. A.. editor. Biogeography and Ecology of Forest Bird Communities. SPB Academic Publishers. The Hague. Netherlands.

Williams. C. B. 1964. Patterns in the balance of nature. London. Academic Press.

Zach, R. and J. B. Falls. 1979. Foraging and territoriality of male Ovenbirds (Aves:Parulidae) in a heterogeneous habitat. Animal Ecology 48:33-52. 
Appendix A. Bird density and pairing success data from 34 forests near Ottawa, Ontario.

\begin{tabular}{|c|c|c|c|c|}
\hline $\begin{array}{c}\text { Site } \\
\text { number* }\end{array}$ & $\begin{array}{c}\text { Ovenbird } \\
\text { density } \\
\text { (\#males/ha) }\end{array}$ & $\begin{array}{c}\text { Red-eyed Vireo } \\
\text { density } \\
\text { (\#males/ha) }\end{array}$ & $\begin{array}{c}\text { Wood Thrush } \\
\text { density } \\
\text { (\#males/ha) }\end{array}$ & $\begin{array}{c}\text { Proportion of } \\
\text { paired male } \\
\text { Ovenbirds } \\
\end{array}$ \\
\hline 1 & 0 & 0.246 & 0 & - \\
\hline 2 & 0 & 0.377 & 0 & - \\
\hline 3 & 0.707 & 0.177 & 0 & 0 \\
\hline 4 & 0.12 & 0 & 0 & 0.500 \\
\hline 5 & 0.105 & 0.209 & 0 & - \\
\hline 6 & 0.202 & 0.504 & 0 & 0.500 \\
\hline 7 & 0 & 0.38 & 0 & - \\
\hline 8 & 0 & 0.277 & 0.185 & - \\
\hline 9 & 0 & 0.068 & 0 & - \\
\hline 10 & 0 & 0 & 0.065 & - \\
\hline 11 & 0 & 0.383 & 0.191 & - \\
\hline 12 & 0.318 & 0.127 & 0.191 & 0.333 \\
\hline 13 & 0.113 & 0.113 & 0 & 0 \\
\hline 14 & 0.152 & 0.356 & 0 & 0.333 \\
\hline 15 & 0 & 0.094 & 0 & - \\
\hline 16 & 0.137 & 0.183 & 0 & 0 \\
\hline 17 & 0.151 & 0.038 & 0 & 0.500 \\
\hline 18 & 0.112 & 0.15 & 0.15 & 0.250 \\
\hline 19 & 0.102 & 0.136 & 0 & 0.667 \\
\hline 20 & 0.151 & 0.03 & 0.151 & 0 \\
\hline 21 & 0.04 & 0.058 & 0.058 & 0.250 \\
\hline 22 & 0.081 & 0.109 & 0.027 & 0.500 \\
\hline 23 & 0.175 & 0.258 & 0.094 & 0.429 \\
\hline 24 & 0.066 & 0.088 & 0.022 & 0 \\
\hline 25 & 0.066 & 0.066 & 0.044 & 0.667 \\
\hline 26 & 0.152 & 0.076 & 0.038 & 0.333 \\
\hline 27 & 0.035 & 0.105 & 0.052 & 0 \\
\hline 28 & 0.063 & 0.063 & 0.013 & 0.333 \\
\hline $29 * *$ & 0.164 & 0.013 & 0.063 & 0.400 \\
\hline $30 * *$ & 0.125 & 0.025 & 0 & 0.750 \\
\hline $31 * *$ & 0.024 & 0.04 & 0.04 & 0.667 \\
\hline 32 & 0.175 & 0.048 & 0.012 & 0.500 \\
\hline 33 & 0.103 & 0.011 & 0.023 & 0.333 \\
\hline 34 & 0.049 & 0.106 & 0.024 & 0.250 \\
\hline
\end{tabular}

* see Appendix B for site characteristics

** continuous forests 
Appendix B. Habitat data from 34 forests near Ottawa, Ontario.

\begin{tabular}{|c|c|c|c|c|c|c|c|c|c|}
\hline $\begin{array}{c}\text { Site } \\
\text { number }\end{array}$ & DBH & $\begin{array}{c}\text { Crown } \\
\text { Loss }\end{array}$ & $\begin{array}{c}\text { Damage } \\
\text { Index }\end{array}$ & $\begin{array}{l}\text { Woody } \\
\text { Debris }\end{array}$ & $\begin{array}{l}\text { Living } \\
\text { Ground } \\
\text { cover }\end{array}$ & $\begin{array}{c}\text { Herb } \\
\text { Height }\end{array}$ & $\begin{array}{l}\text { Shrub } \\
\text { Height }\end{array}$ & $\begin{array}{c}\text { Canopy } \\
\text { Cover }\end{array}$ & $\begin{array}{l}\text { Litter } \\
\text { Depth }\end{array}$ \\
\hline 1 & 0.23 & 53.3 & 3.3 & 0.8 & 10 & 0.1 & 1.1 & 4.3 & 0.06 \\
\hline 2 & 0.2 & 16.8 & 1.1 & 1.2 & 37.3 & 0.1 & 2.5 & 4.4 & 0.08 \\
\hline 3 & 0.14 & 50 & 3 & 3.8 & 51.7 & 0.2 & 0 & 1.8 & 0.09 \\
\hline 4 & 0.18 & 11.7 & 1 & 3.7 & 53.3 & 0.2 & 2.9 & +.3 & 0.11 \\
\hline 5 & 0.27 & 15 & 1.5 & 3.2 & 51.7 & 0 & 0.7 & 2.5 & 0.27 \\
\hline 6 & 0.15 & 15.6 & 1 & 0.8 & 11.1 & 0.1 & 3.1 & 4.9 & 0.23 \\
\hline 7 & 0.22 & 4.4 & 0.6 & 2.1 & 12.2 & 0.2 & 1.3 & 3.6 & 0.16 \\
\hline 8 & 0.15 & 22.2 & 1.7 & 3.3 & 93.3 & 0.2 & 1.7 & 3.2 & 0.24 \\
\hline 9 & 0.33 & 27.8 & 2.1 & 3.8 & 74.4 & 0.5 & 2.1 & + & 0.11 \\
\hline 10 & 0.26 & 26.7 & 1.44 & 2 & 45.6 & 0.2 & 2 & 3.1 & 0.05 \\
\hline 11 & 0.16 & 5.6 & 0.4 & 2.4 & 14.4 & 0.1 & 1.5 & 3.8 & 0.17 \\
\hline 12 & 0.19 & 15.6 & 1.4 & 1 & 40 & 0.1 & 1.3 & 3.9 & 0 \\
\hline 13 & 0.21 & 15 & 1.2 & 0.8 & 76.7 & 0.3 & 3.3 & 3.3 & 0.19 \\
\hline 14 & 0.28 & 26.7 & 2 & 4.7 & 73.3 & 0.3 & 1.1 & 1.9 & 0.26 \\
\hline 15 & 0.2 & 12.2 & 0.9 & 3.3 & 67.8 & 0.2 & 1.1 & 3.4 & 0.07 \\
\hline 16 & 0.19 & 0.8 & 0.1 & 2.8 & 86.7 & 0.5 & 2.6 & 5 & 0.06 \\
\hline 17 & 0.15 & 25.6 & 1.8 & 3.2 & 54.4 & 0.1 & 1.8 & 2.4 & 0 \\
\hline 18 & 0.27 & 27.8 & 2.78 & 5.2 & 97.8 & 0.6 & 1.4 & 3.2 & 0.03 \\
\hline 19 & 0.21 & 6.7 & 0.5 & 3.3 & 5 & 0.1 & 0.8 & 4.5 & 0.25 \\
\hline 20 & 0.19 & 1.7 & 0.2 & 1.6 & +0 & 0.1 & 0 & 3.3 & 0.07 \\
\hline 21 & 0.22 & 29.2 & 2.9 & 2.8 & 27.5 & 0.2 & 1.6 & 3.8 & 0.24 \\
\hline 22 & 0.18 & 0 & 0 & 1.3 & 14.4 & 0.1 & 0 & 4.3 & 0.13 \\
\hline 23 & 0.19 & 16.2 & 1 & 2.5 & 40.7 & 0.1 & 1.3 & 2.5 & 0.46 \\
\hline 24 & 0.15 & 22.5 & 1.7 & 1.4 & 18.3 & 0.1 & 0.6 & 3.8 & 0.28 \\
\hline 25 & 0.21 & 44.7 & 2.8 & 2.7 & 88 & 0.4 & 0.9 & 0.9 & 0.38 \\
\hline 26 & 0.19 & 1.7 & 0.2 & 0.7 & 20 & 0.1 & 0.5 & 4.6 & 0.32 \\
\hline 27 & 0.2 & 14.7 & 1.1 & 4.2 & 50 & 0.3 & 1.9 & 4.1 & 0.1 \\
\hline 28 & 0.36 & 23.8 & 1.8 & 2.2 & 81.1 & 0.9 & 1.3 & 3 & 0 \\
\hline $29 *$ & 0.19 & 22.5 & 1.9 & 4.8 & 35.8 & 0.1 & 1.7 & 3.4 & 0.32 \\
\hline $30^{*}$ & 0.25 & 11.1 & 0.7 & 2.4 & 56.7 & 0.3 & 2.9 & 3.1 & 0.13 \\
\hline $31^{*}$ & 0.18 & 19.4 & 1 & 1.9 & 73.9 & 0.3 & 1.8 & 3.3 & 0.06 \\
\hline 32 & 0.22 & 12.5 & 0.8 & 3.9 & 64.4 & 0.7 & 2.2 & 2.4 & 0.05 \\
\hline 33 & 0.2 & 1.3 & 0.1 & 1.6 & 15.3 & 0.1 & 1.6 & 1.6 & 0.02 \\
\hline 34 & 0.19 & 14.2 & 0.9 & 2.3 & 40.8 & 0.1 & 1.5 & 2.8 & 0.36 \\
\hline
\end{tabular}

* continuous forests 
Appendix B. (cont.) Habitat data from 34 forests near Ottawa, Ontario.

\begin{tabular}{ccccc}
\hline $\begin{array}{c}\text { Site } \\
\text { number }\end{array}$ & $\begin{array}{c}\text { tree } \\
\text { density }\end{array}$ & $\begin{array}{c}\text { tree } \\
\text { height }\end{array}$ & $\begin{array}{c}\text { tree } \\
\text { species } \\
\text { richness }\end{array}$ & $\begin{array}{c}\text { percent } \\
\text { deciduous } \\
\text { species }\end{array}$ \\
\hline 1 & 6.3 & 8.22 & 2 & 100.00 \\
2 & 3.7 & 12.24 & 4 & 100.00 \\
3 & 3.4 & 7.29 & 3 & 100.00 \\
4 & 4.8 & 9.94 & 4 & 0.67 \\
5 & 4.4 & 10.54 & 2 & 100.00 \\
6 & 5 & 11.20 & 4 & 100.00 \\
7 & 7 & 14.40 & 4 & 100.00 \\
8 & 5.3 & 8.53 & 3 & 100.00 \\
9 & 4.2 & 18.33 & 6 & 100.00 \\
10 & 3.3 & 12.55 & 4 & 0.89 \\
11 & 3.4 & 16.33 & 5 & 100.00 \\
12 & 3 & 10.50 & 4 & 0.33 \\
13 & 5.9 & 14.86 & 4 & 100.00 \\
14 & 4.8 & 13.57 & 7 & 0.92 \\
15 & 4.8 & 19.00 & 5 & 100.00 \\
16 & 3.5 & 13.74 & 3 & 100.00 \\
17 & 5.2 & 9.04 & 4 & 0.78 \\
18 & 3.3 & 19.33 & 4 & 100.00 \\
19 & 3.4 & 15.17 & 5 & 0.92 \\
20 & 2.4 & 9.01 & 6 & 0.50 \\
21 & 4.1 & 12.83 & 2 & 100.00 \\
22 & 2.7 & 10.62 & 3 & 0.11 \\
23 & 4.5 & - & - & - \\
24 & 4 & 12.50 & 3 & 100.00 \\
25 & 3.4 & 11.71 & 5 & 100.00 \\
26 & 2.9 & 8.35 & 5 & 0.83 \\
27 & 3.2 & 10.41 & 6 & 0.53 \\
28 & 3.2 & 17.83 & 3 & 100.00 \\
$29 *$ & 3.1 & 11.49 & 4 & 0.75 \\
$30 *$ & 3.7 & 10.29 & 6 & 0.67 \\
$31 *$ & 4.1 & 13.40 & 6 & 0.89 \\
32 & 3.4 & 11.10 & 4 & 100.00 \\
33 & 3.5 & 9.73 & 5 & 0.60 \\
34 & 4.1 & 9.30 & 3 & 100.00 \\
\hline
\end{tabular}

* continuous forests 